NBER WORKING PAPER SERIES

\title{
THE AFFORDABLE CARE ACT AS RETIREE HEALTH INSURANCE: IMPLICATIONS FOR RETIREMENT AND SOCIAL SECURITY CLAIMING
}

\author{
Alan L. Gustman \\ Thomas L. Steinmeier \\ Nahid Tabatabai \\ Working Paper 22815 \\ http://www.nber.org/papers/w22815 \\ NATIONAL BUREAU OF ECONOMIC RESEARCH \\ 1050 Massachusetts Avenue \\ Cambridge, MA 02138 \\ November 2016
}

This work was supported by a grant from the Social Security Administration through the Michigan Retirement Research Center (UM16-02) to the NBER with a subcontract to Dartmouth College. The findings and conclusions expressed are solely those of the authors and do not represent the views of the Social Security Administration, any agency of the Federal government, the Michigan Retirement Research Center or the NBER. Helen Levy provided helpful suggestions. The views expressed herein are those of the authors and do not necessarily reflect the views of the National Bureau of Economic Research.

NBER working papers are circulated for discussion and comment purposes. They have not been peer-reviewed or been subject to the review by the NBER Board of Directors that accompanies official NBER publications.

(C) 2016 by Alan L. Gustman, Thomas L. Steinmeier, and Nahid Tabatabai. All rights reserved. Short sections of text, not to exceed two paragraphs, may be quoted without explicit permission provided that full credit, including $\odot$ notice, is given to the source. 
The Affordable Care Act as Retiree Health Insurance: Implications for Retirement and Social Security Claiming

Alan L. Gustman, Thomas L. Steinmeier, and Nahid Tabatabai

NBER Working Paper No. 22815

November 2016

JEL No. D91,E21,H55,I13,J14,J18,J26,J32

\begin{abstract}
Using data from the Health and Retirement Study, we examine the effects of the Affordable Care Act (ACA) on retirement. We first calculate retirements (and in related analyses changes in expected ages of retirement and/or Social Security claiming) between 2010, before ACA, and 2014, after ACA, for those with health insurance at work but not in retirement. This group experienced the sharpest change in retirement incentives from ACA. We then compare retirement measures for those with health insurance at work but not in retirement with retirement measures for two other groups, those who, before ACA, had employer provided health insurance both at work and in retirement, and those who had no health insurance either at work or in retirement. To complete a difference-in-difference analysis, we make the same calculations for members of an older cohort over the same age span. We find no evidence that ACA increases the propensity to retire or changes the retirement expectations of those who, before ACA, had coverage when working but not when retired.
\end{abstract}

An analysis based on a structural retirement model suggests that eventually ACA will increase the probability of retirement by those who initially had health insurance on the job but did not have employer provided retiree health insurance. But the retirement increase is quite small, only about half a percentage point at each year of age. The model also suggests that much of the effect of ACA on retirement will be realized within a few years of the change in the law.

Alan L. Gustman

Department of Economics

Dartmouth College

Hanover, NH 03755-3514

and NBER

ALAN.L.GUSTMAN@DARTMOUTH.EDU
Nahid Tabatabai

Department of Economics

Dartmouth College

Hanover, N.H. 03755

Nahid.Tabatabai@dartmouth.edu

Thomas L. Steinmeier

Department of Economics

Texas Tech University

Lubbock, TX 79409

thomas.steinmeier@ttu.edu 


\title{
The Affordable Care Act as Retiree Health Insurance: Implications for Retirement and Social Security Claiming
}

\author{
Alan L. Gustman, Thomas L. Steinmeier, and Nahid Tabatabai
}

The Affordable Care Act (ACA) was passed in 2010. It increases the availability of health insurance for those who did not have coverage from their employer, or who were not working. ACA also provides a range of subsidies based on family income. It mandates standards for qualified plans, and imposes penalties on individuals without insurance and on certain employers who did not insure their full-time workers. Different provisions of the legislation continue to be phased in over time. ${ }^{1}$

Policy concerns include the question of whether ACA encourages earlier retirement. Concern about this issue stems from the findings in an extensive literature suggesting retiree health insurance accelerates retirement. ${ }^{2}$ ACA may be expected to have a similar effect to retiree health insurance since it provides health insurance to those who would not be covered until they become eligible for Medicare should they choose to retire before age 65. If ACA accelerates retirement, this side effect might undermine decades of public policies that were designed to increase the retirement age. ${ }^{3}$

\footnotetext{
${ }^{1}$ The tax on individuals who are not insured has increased from the higher of $\$ 95$ per adult, or 1 percent of household income in 2014; to $\$ 325$, or 2 percent of income in 2015; to $\$ 695$, or 2.5 percent of household income in 2016.

${ }^{2}$ Studies of the relation of retiree health insurance to retirement include Clark (2015), Currie and Madrian (1999), French and Bailey Jones (2011), Gilleskie and Blau (2006), Gustman and Steinmeier (1994, 2000), Madrian (1994), Marton and Woodbury (2006) and Nyce et al. (2011). For studies of the relation between retirement and Social Security benefit claiming, see Glickman and Hermes (2015), Gustman and Steinmeier (2015), Henriques (2012), Shoven and Slavov (2012, 2014), and Song and Manchester (2007).

${ }^{3}$ Policies designed to encourage delayed retirement include: the increase in the Social Security full retirement age; the abolition of the earnings test after full retirement age; the increase in
} 
In contrast to the suggestion from the literature on retiree health insurance, Levy, Buchmueller and Nikpay (2015) do not find those under the age of 65 have changed their retirements following the implementation of ACA. Their approach is to contrast changes in retirements through mid-2015 between individuals residing in states that participated in ACA with changes in retirements observed for individuals from states that did not participate. They recognize that too short a time may have elapsed for the full effects of ACA on retirement to be observed. ${ }^{4}$ Nevertheless, if their analysis holds over the longer term, it would suggest there are no unintended side effects of ACA on retirement to be of concern to policy makers.

A goal of this paper is to help to fill the gap in our understanding of the effects of the Affordable Care Act (ACA) on retirement. Our aim is to bridge the contradictory findings between the retiree health literature and the recent analysis of the retirement effects of ACA.

We focus on three major groups of employed individuals, categorized by their employer provided health insurance coverage before the adoption of ACA. A first group consists of individuals with employer provided health insurance when working, but with no employer provided retiree health insurance to cover them should they retire before age 65. This group is subject to an incentive from ACA that is similar to the incentive created by retiree health

Social Security's delayed retirement credit; the abolition of mandatory retirement; and enforcement of rules requiring defined benefit pension plans to be actuarially fair in determining benefits after normal retirement.

${ }^{4}$ Levy et al. (2015) suggest the problems with the start-up of the exchanges may have adversely affected perceptions as to the availability of alternatives to employer provided insurance. The short time frame also creates other reasons for the absence of an observed effect. There has been little time for those very near retirement age to reoptimize. For example, to fund an earlier retirement, an individual may need to accumulate additional wealth. It might also be that the effects of ACA on retirement will not be visible until the near retirement age population better understands the change in retirement incentives introduced by ACA. 
insurance. ACA would not induce as large a change in the marginal incentive to retire for two other groups, those whose employers provide health insurance both on the job and in retirement, and those with no employer provided health insurance either at work or when retired.

First, using two cohorts from the Health and Retirement Study, we conduct a difference-indifference analysis of the actual effects of ACA on retirement in the short term. This analysis uses data from the HRS Mid Boomer cohort to calculate the differences in retirement outcomes between those whose retirement incentives are modified by ACA and those whose marginal incentives are not affected by ACA. Retirement changes are calculated over the 2010 to 2014 period. The analysis then compares the changes between the three groups over the period since ACA was adopted with the analogous changes over an earlier period when ACA did not affect incentives. Note that our approach, comparing the differences in outcomes among these three groups between two periods, differs from, and is somewhat complementary to, the approach taken by Levy, Buchmueller and Nikpay (2015).

In view of the possibility that it is too early to find effects of ACA on actual retirements, our second step is to extend the time period for measuring retirement. We do this by considering changes in respondent reports of their expected retirement and Social Security claiming dates. For Mid Boomers the changes in expectations are calculated for each of the coverage groups over the 2010 to 2014 period. For Early Boomers calculations are made over the comparable age span. Many expect to retire after 2014. Thus the period of analysis is not limited to the 20102014 period used to observe actual changes in retirements. Using the change in retirement expectations as the dependent variable allows individuals to consider changes over a much longer period. As a result, it allows them to enhance the attractiveness of retiring earlier by changing saving and other related behaviors, changes that are not possible in the short run. 
Our third step is to project the potential effects of ACA over an even longer period. For this exercise, we use a structural model of retirement. The model was previously estimated to explain the retirement behavior observed for members of the original HRS cohort. Our model includes the role that health insurance plays in buffering against small probability catastrophic health events that may create very large declines in assets and consumption.

To simulate the effects of ACA on retirements, we introduce ACA into the budget constraint facing each individual. This procedure allows us to simulate the effects of ACA in the long run, i.e., the full adjustments in retirement that might be observed for those who entered the labor market with ACA already in place. It also allows us to simulate adjustments in outcomes over the short and intermediate terms. We do this by introducing ACA at an older age and allow respondents to reoptimize their behavior in view of the unexpected change in the law. Thus a major advantage of the structural approach is that it allows us to compare the effects of ACA on retirement in the short, intermediate and long run.

We are aware of an important potential pitfall in analyzing the relation of retiree health insurance to retirement. Availability of employer provided health insurance is correlated with coverage by a defined benefit pension. Previous analyses have at times confounded the effects of retiree health insurance with those of DB pensions. To avoid this pitfall, after we explore the retiree health insurance--pension relation in descriptive data, we standardize for the influence of correlated pension incentives on retirement in a multivariate, and then in a structural setting. This is designed to eliminate any specification error that would otherwise result from failing to standardize for the covariance between employer provided health insurance and incentives from pensions. 
In Section II we estimate the size of the groups classified by their health insurance coverage in 2010. We use the panel feature of the HRS to document the changes in employer provided health insurance at work and in retirement between 2010, before ACA, and 2014, after ACA was implemented. These descriptive data are followed by tables that include other sources of health insurance beside that provided by employers, including health insurance purchased in the private market, coverage from a spouse's employment, and from other sources. After that we explore the relation between employer provided health insurance and two key covariates, pension plan coverage and plan type.

Section III estimates the relation between initial type of health insurance coverage and retirements observed between 2010 and 2014. We then compare retirements by initial health insurance coverage between the cohort affected by ACA and an older cohort over a four year period involving the same initial age span.

Section IV examines changes in retirement intentions before vs. after adoption of the ACA. We focus on changes in intended retirement dates, and on changes in intended date of claiming Social Security benefits. Once again we conduct a difference-in-difference analysis of retirement intentions. This compares differences in retirement intentions between members of the younger cohort affected by ACA over a four year span with differences in retirement intentions for members of an older cohort over the same age span. The difference-in-difference analysis standardizes for any longer term trends, as well as changes in actual retirements and in expectations that arise over the period just before retirement age.

Section V modifies our structural model to project responses to ACA in the long term, as well as in the short run and intermediate run. Section VI concludes. 
II. Descriptive Analysis of the Availability of Health Insurance

We arrange the descriptive analysis around three groups. ACA is most likely to affect marginal retirement incentives for members of the first group, those who had health insurance on the job, but did not have employer provided health insurance should they retire before age 65 . After ACA, the private health insurance market and exchanges provide retiree health insurance, often subsidized, reducing the incentive for members of this first group to stay on the job. In contrast, ACA does not affect incentives for a second group, those who before its implementation had employer provided health insurance on the job and in retirement. Nor does it affect incentives for those who initially had no employer provided health insurance, either while working or when retired. ${ }^{5}$

The data in this section is from members of the Mid Boomer cohort of the Health and Retirement Study, individuals who were born from 1954 through 1959. We restrict the sample to respondents who were ages 51 to 56 when they first entered the HRS. ${ }^{6}$ Observations begin in 2010, before ACA affected the availability of health insurance. The last HRS observations available at the time of the writing of this study are from 2014.

\footnotetext{
${ }^{5}$ Second order effects would arise if, in response to ACA, employers changed the relative availability of health insurance on the job and in retirement. There is no evidence of major changes in employer offerings after ACA was adopted, however. There also may be other second order effects of ACA. Employers might, for example, change the subsidies for employee vs. retiree health insurance, either modifying required contributions, or changing deductibles and copays. Retirement incentives would also be affected if employers created or modified any compensating wage differentials. HRS does not provide information on the extent of employer subsidization of health insurance. Nor has ACA been in effect long enough to reliably identify any changes in compensating wage differentials.

${ }^{6}$ By limiting the analysis to individuals who were ages 51 to 56 when they entered the HRS, we exclude those who entered the HRS before 2010 as a younger or older spouse to an age eligible household member. That is, we exclude cases where the spouse, but not the Mid Boomer respondent, was 51 to 56 years old at the time of entering the survey.
} 
IIA. Health Insurance Coverage from Employers.

Table 1 begins with data on insurance from work related sources only. The sample in each year is restricted to those who have a current job in that year. Percentages of observations in the indicated year are reported below the counts in each cell.

From row 1, column 1 of Table 1, 1054 respondents in 2010, or 39.3 percent of 2010 respondents who were currently employed, had employer provided health insurance while working on their current job, but did not have employer provided health insurance in retirement. This juxtaposition of health insurance availability generates the strongest first order incentive influencing retirement prior to ACA, encouraging the individual to postpone retiring. Moving down column 1, 42.7 percent of respondents had no employer provided health insurance either on their current job or in retirement. When a person has no employer provided health insurance either before or after retirement, health insurance does not differentially affect the incentive to retire. The third group includes 18 percent of employed respondents. In 2010, these individuals had employer provided health insurance whether working or retired, so that employee provided health insurance did not create a strong incentive affecting retirement. ${ }^{7}$

There are very small differences between years in the proportion falling within each health insurance group. ${ }^{8}$ This can be seen by comparing values across the three columns of Table

\footnotetext{
${ }^{7}$ The relative sizes of each of the three groups are similar for both males and females. When the sample is restricted to those who had been on the job for at least ten years, the fraction with health insurance on the job, but no health insurance in retirement, increases slightly. For example, in 2010, 42.6 percent of the sample of long term job holders had health insurance on the job, but not in retirement. The group with health insurance both when working and when retired increases from 18.0 percent of all employed to 22.2 percent of long term employed. ${ }^{8}$ Comparing columns 1 and 3 of Table 1, bottom row, between 2010 and 2014, the total number respondents to the survey who reported themselves as employed declined 14.2 percent (1 -
} 
1. Between 2010 and 2014, the fraction of the employed with health insurance on the job and no health insurance in retirement decreases from 39.3 percent to 37.6 percent of the employed. The fraction with no health insurance either on the job or in retirement decreases from 42.7 percent of the employed in 2010 to 42.4 percent in 2014. Lastly, the percentage of employees with health insurance both at work and when retired increases from 18.0 to 20.0 percent.

Table 1: Employer Provided Health Insurance on Current Job and in Retirement in 2010, 2012 and 2014 (percentages of total are in parentheses)

\begin{tabular}{|l|c|c|c|}
\hline & 2010 & 2012 & 2014 \\
\hline HI on Job; No HI in Retirement & 1054 & 991 & 865 \\
& $(39.3)$ & $(38.9)$ & $(37.6)$ \\
\hline No HI on Job; No HI in Retirement & 1144 & 1092 & 976 \\
& $(42.7)$ & $(42.9)$ & $(42.4)$ \\
\hline HI on Job; HI in Retirement & 483 & 462 & 459 \\
& $(18.0)$ & $(18.2)$ & $(20.0)$ \\
\hline Total & 2681 & 2545 & 2300 \\
\hline
\end{tabular}

*The sample is restricted to Mid Boomers who had a current job and were ages 51 to 56 when they first entered the survey.

The summary statistics in Table 1 do not provide a full picture of the changes experienced by those falling in different health insurance groups before ACA. Those in one category of health insurance in 2010 frequently are found in another category in $2014 .{ }^{9}$ While the flows into and out of a particular category roughly offset, it would appear from the row and column totals of Table 1 that the changes between 2010 and 2014 are relatively small. Similarly,

2300/2681). The attrition rate for the overall sample of Mid Boomers between 2010 and 2014 is $17.5 \%(691 / 3940)$.

${ }^{9}$ For this analysis, Table 2 is restricted to Mid Boomers who responded to the HRS in 2010 and 2014, and who held a job in those years. For completeness, we also include a small category consisting of those who report having health insurance in retirement, but not on the current job. Presumably their coverage must have come from a previous employer, or it may simply be the result of reporting error. 
the summary statistics in the final column and bottom row of Table 2 do not suggest major changes in health insurance status in the aggregate.

In fact, from the perspective of individuals there is a substantial probability of moving from one health insurance category to another, although the probability of having the same coverage at work and in retirement in 2014 as in 2010 is substantially greater than 50 percent. Consider row 1 of Table 2. In 2010, before the ACA was implemented, 40.9 percent of respondents were covered by health insurance on their current job, but not in retirement. Looking across row 1, by 2014, 66.2 percent of those individuals (522/789) still had health insurance on their current job, but not in retirement. From row 1, column 2, however, by 2014, 13.6 percent (107/789) had lost health insurance on their current job and still had no health insurance in retirement. In contrast, among those with health insurance on their current job in 2010 but not in retirement, by 201419.8 percent (156/789) had maintained their insurance on their current job, while also gaining retiree health insurance.

From row 2 of Table 2, which begins with the 40.3 percent of respondents in 2010 who had no health insurance either on the job or in retirement, we see that 16.6 percent (129/777) gained health insurance on the job by 2014. An additional 6.9 percent (54/777) of those with no insurance in 2010 gained health insurance both while employed in their 2014 job and also when they retired.

Lastly, although 54.5 percent (188/345) of those who had both current and retiree health insurance in 2010 were also insured in 2014, 32.8 percent (113/345) lost their retiree benefits, although they maintained insurance on their current job, while by 2014, 11.0 percent (38/345) no longer had either current or retiree health insurance. 
Table 2: Number of Respondents by Health Insurance Coverage on Current Job and in Retirement, 2010 to 2014 (percentages of total are in parentheses)

\begin{tabular}{|l|c|l|c|c|c|}
\hline & \multicolumn{5}{|c|}{2014} \\
\hline 2010 & $\begin{array}{l}\text { HI Cur Job; } \\
\text { No HI Ret. }\end{array}$ & $\begin{array}{l}\text { No HI Cur } \\
\text { Job; No HI } \\
\text { Ret }\end{array}$ & $\begin{array}{l}\text { HI Cur Job; } \\
\text { HI Ret }\end{array}$ & $\begin{array}{l}\text { No HI Cur } \\
\text { Job; HI Ret }\end{array}$ & Row Total \\
\hline HI Cur Job; & 522 & 107 & 156 & 4 & 789 \\
No HI Ret. & $(66.2)$ & $(13.6)$ & $(19.8)$ & $(.005)$ & $(40.9)$ \\
\hline No HI Cur & 129 & 593 & 54 & 1 & 777 \\
Job; No HI & $(16.6)$ & $(76.3)$ & $(6.9)$ & $(.001)$ & $(40.3)$ \\
Ret & 113 & 38 & 188 & 6 & $(1.7)$ \\
\hline HI Cur Job; & $(32.8)$ & $(11.0)$ & $(54.5)$ & 10 & $(17.9)$ \\
HI Ret & 2 & 5 & 1 & $(55.6)$ & $(0.1)$ \\
\hline No HI Cur & $(11.1)$ & $(27.8)$ & $(5.6)$ & 21 & 1929 \\
Job; HI Ret & 766 & 743 & 399 & $(1.1)$ & $(100)$ \\
\hline Column Total & $(39.7)$ & $(38.5)$ & $(20.7)$ & & \\
\end{tabular}

* Sample includes those respondents in 2010 and 2014 who had a current job in each of those years.

IIB. Health Insurance Coverage from All Sources

The goal of ACA is to increase health insurance coverage, whether that coverage is through the employer or from other sources. The shares of respondents with each source of employer provided coverage in 2010 are reported in the last column of Table 3. Shares of employed respondents by source of coverage in 2014 are reported in the bottom row. The cells in the table trace the changes in sources of coverage between 2010 and 2014, before and after ACA. For purposes of comparison, Appendix Table 1 reports the same flows for the Early Boomer cohort between 2004 and 2008, when they fell in the same age span as the Mid Boomers, but were unaffected by the ACA.

Health insurance coverage is considerably higher when one considers sources beyond own current employer. Looking down the last column of Table 3, these other sources of coverage increase the health insurance coverage rate from 56 percent of employed individuals based on 
insurance from own employer up to 81 percent. (In 2004 the Early Boomer cohort shows an analogous increase from considering other sources of health insurance from $59 \%$ to $86 \%$.) Aside from own employment, in 2010 the spouse's employer (13\%), private insurance (4\%) and insurance through self-employment (3\%) are the three most important sources of coverage. ${ }^{10}$ The results in Appendix Table 1 for Early Boomers in 2004 are similar.

From row 9, right hand column (12), when health insurance coverage from private insurance, Medicare, Medicaid, from military service and from other sources are included, 19 percent of the continuously employed had no health insurance in 2010. (In 200414 percent were uninsured.) After ACA, from row 10, column 11 of Table 3, the group with no insurance had fallen to 15 percent. Thus between 2010 and 2014, the share of currently employed individuals without health insurance coverage had fallen by about 4 percentage points. (Between 2004 and 2008, there was a 1 percentage point decline in the share of the employed who were uninsured.) Among 1080 respondents who had coverage from a current employer in 2010, 87 percent (941) had insurance from a current employer four years later. Of the remainder, 5.2 percent (56/1080) ended up with no health insurance; 2.8 percent (30/1080) were newly insured through a spouse, and 2.4 percent (26/1080) had purchased private insurance.

Of 373 individuals who had no insurance in 2010, just over half $(50.9$ percent $=190 / 373)$ still had no insurance by 2014; 23.1 percent (86/373) gained insurance from a current employer; 11.8 percent (44/373) secured private insurance; and 7.5 percent (28/373) gained coverage from Medicaid. The transitions observed between 2004 and 2008, before the advent of ACA, were similar.

${ }^{10}$ Disaggregating the Mid Boomer statistics by gender, 11.7 percent of males and 13.5 percent of females are covered via their spouse's health insurance. 
Not shown in Table 3, the percentage of the sample with retiree health insurance from their own current employer, a previous employer, or a spouse’s employer, increased from 19.2 percent in 2010 to 22.5 percent 2014.

There are three lessons to take away from these data. The first is that the transitions from the period before to after ACA are not very different from the comparable transitions observed for an older cohort over the same age span. The second lesson is a caveat about our methodology. We will attempt to measure the effects of ACA on retirement incentives by focusing on the group that, before ACA, had employer provided health insurance on the job, but not in retirement. We assume they gain coverage in retirement from ACA that they otherwise would not have had, so their incentive to keep on working is reduced. But as Table 3 demonstrates, some of them would have secured health insurance in retirement from the other sources listed in that table. For those respondents, we will overstate the effects of ACA on their retirement incentives. Members of other groups would also have experienced a change in their insurance status before reaching retirement age. For some, ACA would have a greater effect on their retirement incentives than we are supposing. The third lesson is that others would have secured health insurance coverage outside of their own employment. This means that our attempt to identify the affected group by focusing only on insurance from the employer tells only part of the story. This approximation should be borne in mind when interpreting our later results. 
Table 3: Number of Employed Respondents by the Source of Insurance in 2010 and 2014

\begin{tabular}{|c|c|c|c|c|c|c|c|c|c|c|c|c|}
\hline & \multicolumn{12}{|c|}{2014} \\
\hline 2010 & $\begin{array}{c}\text { Current } \\
\text { Employer } \\
\\
1\end{array}$ & $\begin{array}{c}\text { Pre- } \\
\text { vious } \\
\text { Employ } \\
\text { er } \\
2\end{array}$ & $\begin{array}{l}\text { Self } \\
\text { Emp- } \\
\text { loyed } \\
\text { Bus- } \\
\text { iness } \\
3\end{array}$ & $\begin{array}{c}\text { Spouse } \\
\text { Employer } \\
\text { - current } \\
\text { or former } \\
4\end{array}$ & $\begin{array}{c}\text { Private } \\
\text { Insurance } \\
\text { Purchase } \\
5\end{array}$ & $\begin{array}{c}\text { Medicare } \\
\text { (disability } \\
\text { ?) }\end{array}$ & $\begin{array}{c}\text { Medi- } \\
\text { caid } \\
\\
7\end{array}$ & Military & $\begin{array}{l}\text { With } \\
\text { Gov. } \\
\text { Sub- } \\
\text { sidy } \\
\text { 9* }\end{array}$ & $\begin{array}{c}\text { Purchas- } \\
\text { ed on } \\
\text { Gov. } \\
\text { Ex- } \\
\text { change } \\
10^{*}\end{array}$ & $\begin{array}{c}\text { No } \\
\text { insur- } \\
\text { ance } \\
\\
11\end{array}$ & $\begin{array}{c}\text { Row } \\
\text { Total } \\
\\
12\end{array}$ \\
\hline 1-Current Employer & 941 & 12 & 3 & 30 & 26 & 3 & 3 & 6 & 4 & 5 & 56 & $\begin{array}{l}1080 \\
56 \%\end{array}$ \\
\hline $\begin{array}{l}\text { 2-Previous } \\
\text { Employer }\end{array}$ & 7 & 12 & 1 & 2 & 2 & 0 & 0 & 1 & 1 & 1 & 1 & $\begin{array}{l}26 \\
1 \%\end{array}$ \\
\hline $\begin{array}{l}\text { 3-Self Employed } \\
\text { Business }\end{array}$ & 4 & 0 & 31 & 1 & 6 & 0 & 1 & 1 & 0 & 0 & 10 & $\begin{array}{c}54 \\
3 \%\end{array}$ \\
\hline $\begin{array}{l}\text { 4-Spouse Employer } \\
\text { - current or former }\end{array}$ & 51 & 0 & 5 & 167 & 10 & 1 & 2 & 2 & 0 & 1 & 11 & $\begin{array}{l}249 \\
13 \%\end{array}$ \\
\hline $\begin{array}{l}\text { 5-Private Insurance } \\
\text { Purchase (includes } \\
\text { AARP and others) }\end{array}$ & 14 & 0 & 7 & 6 & 27 & 1 & 5 & 0 & 0 & 0 & 11 & $\begin{array}{c}71 \\
4 \%\end{array}$ \\
\hline $\begin{array}{l}\text { 6-Medicare } \\
\text { (disability?) }\end{array}$ & 0 & 0 & 0 & 1 & 1 & 9 & 0 & 0 & 2 & 2 & 2 & $\begin{array}{c}13 \\
1 \%\end{array}$ \\
\hline 7-Medicaid & 8 & 0 & 0 & 1 & 1 & 1 & 15 & 1 & 0 & 0 & 10 & $\begin{array}{l}37 \\
2 \%\end{array}$ \\
\hline 8- Military & 1 & 0 & 0 & 0 & 2 & 0 & 0 & 21 & 0 & 0 & 2 & $\begin{array}{l}26 \\
1 \%\end{array}$ \\
\hline 9-No insurance & 86 & 0 & 6 & 14 & 44 & 2 & 28 & 3 & 9 & 10 & 190 & $\begin{array}{l}373 \\
19 \%\end{array}$ \\
\hline 10-Column Total & $\begin{array}{l}1112 \\
58 \%\end{array}$ & $\begin{array}{l}24 \\
1 \%\end{array}$ & $\begin{array}{r}53 \\
3 \%\end{array}$ & $\begin{array}{l}222 \\
12 \%\end{array}$ & $\begin{array}{l}119 \\
6 \%\end{array}$ & $\begin{array}{l}17 \\
1 \%\end{array}$ & $\begin{array}{c}54 \\
3 \%\end{array}$ & $\begin{array}{c}35 \\
2 \%\end{array}$ & $\begin{array}{l}16 \\
1 \%\end{array}$ & $\begin{array}{l}19 \\
1 \%\end{array}$ & $\begin{array}{l}293 \\
15 \%\end{array}$ & $\begin{array}{c}1929 \\
100 \%\end{array}$ \\
\hline
\end{tabular}

* This sample is constrained to include those who were currently employed in 2010 and in 2014. Columns 9 and 10 are not mutually exclusive. These are subsets of private insurance purchase. 


\section{C. Health Insurance Coverage and Pensions}

To understand the relationship between retirement and retiree health insurance, as Gustman and Steinmeier (1994) strongly suggests, one must eliminate the effects of any covariation with incentives created by defined benefit pensions. There is a very close relationship between coverage by a defined benefit pension and the availability of retiree health insurance. Omitting the incentive created by an early retirement spike due to a defined benefit pension from a retirement analysis invites specification error. The effect on retirement of the omitted pension incentive, which varies with the terms of the pension benefit formula as well as the work history of the covered individual, will be attributed to retiree health insurance.

Descriptive data on the relation between pension coverage and the availability of employer provided retiree health insurance, and type of pension plan and the availability of employer provided retiree health insurance, are reported in Table 4. From the bottom row, columns 1 and 2, we see that $45.2(1212 / 2681)$ percent of the sample has no pension from their current job.

Table 4: Pension Plan Coverage and Plan Type for Pension from Current Job by Health Insurance Coverage, Mid Boomers 2010, Number of Observations

\begin{tabular}{|l|c|c|c|c|c|}
\hline & Total & No Pens & DB only & DC only & Both \\
\hline HI job; No HI ret & 1054 & 266 & 191 & 386 & 205 \\
\hline No HI job; No HI ret & 1144 & 885 & 63 & 154 & 37 \\
\hline HI job; HI ret & 483 & 61 & 105 & 179 & 137 \\
\hline Total & 2681 & 1212 & 359 & 719 & 379 \\
\hline
\end{tabular}

Turn to Table 5, which reports the column percentages of Table 4. From column 2, row 3, we see that only 5 percent of those with no pension on their current job have health insurance in retirement. From Table 5, row 2, column 2, almost three fourths (73 percent) of those who do not have a pension on their current job also do not have either health insurance on that job or in retirement. Just over one fifth of those without a pension (21.9 percent) has health insurance on the job, but does not have retiree health insurance. 
Looking across row 1 of Table 5, whatever the pension plan type, 53 to 54 percent of those with a pension have health insurance on the job, but do not have retiree health insurance. The next most likely outcome for those with a pension is to have both health insurance on the job and retiree health insurance. That probability is highest for those with both a DB and DC pension at 36.1 percent. Of those with a DB plan only, 29.2 percent have employer provided insurance both on the job and in retirement. In addition, 24.9 percent of those with a 'DC plan only' have health insurance both when working and into retirement. Roughly a fifth of those with a DB only or DC plan only have no health insurance either when working or retired (17.5 percent and 21.4 percent respectively). Those who have both DB and DC pensions have only a 9.8 percent chance of having no health insurance both when working and when retired.

Table 5: Type of Health Insurance Coverage Conditional on Plan Type for Pensions from Current Job, Mid Boomers, 2010

\begin{tabular}{|l|c|c|c|c|c|}
\hline & Total & No Pens & DB only & DC only & Both \\
\hline HI job; No HI ret & 39.3 & 21.9 & 53.2 & 53.7 & 54.1 \\
\hline $\begin{array}{l}\text { No HI job; No HI } \\
\text { ret }\end{array}$ & 42.7 & 73.0 & 17.5 & 21.4 & 9.8 \\
\hline HI job; HI ret & 18.0 & 5.0 & 29.2 & 24.9 & 36.1 \\
\hline Total & 100.0 & 100.0 & 100.0 & 100.0 & 100.0 \\
\hline
\end{tabular}

*Column percentages from Table 4.

Table 6 reports the type of pension conditional on retiree health insurance coverage on the current job and/or retiree health insurance. From the bottom row, the percentages of the currently employed with a DB pension only, a DC pension only, and both types, are 13.4, 26.8 and 14.1 percent respectively. (Similar results are found when plan type is computed for pensions from any job, not just the current job.) In Table 6, row 3, we see that half of those with retiree health insurance have a DB plan only, or both a DB and a DC plan on their current job $(21.7+28.4)$. Yet of the total sample, only 27.5 percent have a DB plan, whether alone or in combination with a DC plan. Given the overwhelming evidence that DB pension incentives 
strongly influence retirement outcomes, this confirms the importance of controlling for the relationship between retiree health insurance and coverage by a defined benefit plan in retirement equations.

Table 6: Type of Pension Conditional on Type of Health Insurance Coverage from Current Job, Mid Boomers, 2010

\begin{tabular}{|l|c|c|c|c|c|}
\hline & Total & No Pens & DB only & DC only & Both \\
\hline HI job; No HI ret & 100 & 25.2 & 18.1 & 36.6 & 19.4 \\
\hline $\begin{array}{l}\text { No HI job; No HI } \\
\text { ret }\end{array}$ & 100 & 77.4 & 5.5 & 13.5 & 3.2 \\
\hline HI job; HI ret & 100 & 12.6 & 21.7 & 37.1 & 28.4 \\
\hline Total & 100 & 45.2 & 13.4 & 26.8 & 14.1 \\
\hline
\end{tabular}

*Row percentages from Table 4 .

Instead of sorting individuals based on type of pension, Tables 7, 8, and 9 include only those who are covered by a pension on their current job and sort them by pension wealth quartile. Table 7 contains the raw numbers in each cell, while Tables 8 and 9 report relevant row and column percentages.

Table 7: Number of Employed Respondents by Type of Health Insurance Coverage and Pension Plan Wealth Quartile, Mid Boomers with Pension Wealth for Pensions from Current Job, 2010

\begin{tabular}{|l|c|c|c|c|c|}
\hline & Total & $0-25 \%$ & $25-50 \%$ & $50-75 \%$ & $75-100 \%$ \\
\hline $\begin{array}{l}\text { HI job; No HI } \\
\text { ret }\end{array}$ & 785 & 201 & 213 & 197 & 174 \\
\hline $\begin{array}{l}\text { No HI job; No } \\
\text { HI ret }\end{array}$ & 261 & 109 & 70 & 44 & 38 \\
\hline HI job; HI ret & 424 & 98 & 82 & 131 & 113 \\
\hline Total & 1470 & 408 & 365 & 372 & 325 \\
\hline
\end{tabular}

From Tables 7, row 3, we see that as pension wealth increases, so does the share of respondents who have both health insurance on the job and health insurance in retirement. From row 2 of Table 7, the number with no health insurance either on the job or in retirement declines as pension wealth increases. 
Table 8: Type of Health Insurance Coverage Conditional on Plan Wealth Quartile, Mid Boomers with Pension Wealth from Current Job, 2010

\begin{tabular}{|l|c|c|c|c|c|}
\hline & Total & $0-25 \%$ & $25-50 \%$ & $50-75 \%$ & $75-100 \%$ \\
\hline HI job; No HI ret & 53.3 & 49.1 & 58.4 & 52.8 & 53.5 \\
\hline $\begin{array}{l}\text { No HI job; No HI } \\
\text { ret }\end{array}$ & 17.7 & 26.7 & 19.2 & 11.8 & 11.7 \\
\hline HI job; HI ret & 28.8 & 24.1 & 22.5 & 35.3 & 34.8 \\
\hline Total & 100.0 & 100.0 & 100.0 & 100.0 & 100.0 \\
\hline
\end{tabular}

*Column percentages of Table 7 .

Table 8 reports the column percentages from Table 7. Looking across row 3, the percentage with health insurance on the job and in retirement rises from 24.1 percent of those in the lowest pension wealth category (column 2, row 3) to 34.8 percent of those in the highest pension wealth category (column 5, row 3).

Table 9 reports the row percentages from Table 7. Looking across row 3, we see the share of those with health insurance at work and in retirement that comes from each pension wealth category. From column 4, row 3, 30.9 percent of those with retiree health insurance come from the third quartile of respondents ranked by pension wealth. Those falling in the highest pension wealth quartile account for a smaller share of those with retiree health insurance at 26.7 percent.

Table 9: Level of Plan Wealth Quartile Conditional on Type of Health Insurance Coverage, Mid Boomers with Pension Wealth from Current Job, 2010

\begin{tabular}{|l|c|c|c|c|c|}
\hline & Total & $0-25 \%$ & $25-50 \%$ & $50-75 \%$ & $75-100 \%$ \\
\hline $\begin{array}{l}\text { HI job; No HI } \\
\text { ret }\end{array}$ & 100.0 & 25.6 & 27.1 & 25.1 & 22.2 \\
\hline $\begin{array}{l}\text { No HI job; No } \\
\text { HI ret }\end{array}$ & 100.0 & 41.8 & 26.8 & 16.9 & 14.6 \\
\hline HI job; HI ret & 100.0 & 23.1 & 19.3 & 30.9 & 26.7 \\
\hline Total & 100.0 & 27.8 & 24.8 & 25.3 & 22.1 \\
\hline
\end{tabular}

*Row percentages of Table 7. 


\section{Health Insurance Coverage and Actual Retirement Age}

Levy, Buchmueller and Nikpay (2015) studied the effects of ACA on actual retirements by relating the probability of retirement to the availability of ACA in the indicated state. We begin with a simple relation between observed retirements (an answer from the CPS type labor market status question in the HRS that the individual was retired in 2014 after having reported a job in 2010) and the type of health insurance held.

Table 10 reports retirement rates over a four year period for the three groups of employed, categorized by their health insurance coverage in the base period. Retirements for those in the Mid Boomer cohort are reported in column 1. Retirements by members of the Early Boomer cohort are in column 2. Differences in retirement rates between cohorts are reported in column 3. The row headings differentiate the three groups according to their employer provided health insurance while working and when retired.

If the results in Table 10 were produced by a natural experiment, the differences in column 3 would indicate the effect of ACA on retirement. The expectation would be that retirement rates would increase by more for those in row 1 of the table since ACA reduces their marginal incentive to stay at work, while it does not affect marginal incentives for members of other groups.

There are two takeaways from Table 10, neither of which is very helpful in isolating the relation between ACA and retirement. First, looking down column 1, retirement is higher in the Mid Boomer cohort for those with health insurance both on the job and in retirement (row 3, 7.6 percent) than it is for those with health insurance on the job but not in retirement (row 1, 3.6 percent). But retirements are even lower for those with no health insurance on the job or in retirement (row 2, 2.7 percent). A similar relation is found for the Early Boomer cohort. 
The second take away is from column 3 . Here we compare changes in retirement over the four year age span between cohorts. This comparison suggests that the absolute reduction in retirement was greater over the period ACA was phased in for those who had employer provided health insurance both on the job and in retirement than it was for members of the other two health insurance groups. The fact that retirements were reduced for all three groups probably reflects the effects of the Great Recession. In particular the labor supply response probably discouraged early retirements. In contrast, the policies adopted by employers to deal with downturn in demand are likely to have encouraged retirements, but these policies probably differed among employers offering different health insurance options. The changes in retirements observed in column 3 may be expected to reflect the joint effects of ACA and the different reactions to the Great Recession. In any case we can find no direct evidence in simple descriptive statistics that ACA accelerated retirements.

Table 10: Percent Who Retired Over Four Year Period, Mid Boomer and Early Boomer Cohorts

\begin{tabular}{|l|c|c|c|}
\hline & $\begin{array}{c}\text { Percent Mid } \\
\text { Boomers Who } \\
\text { Retired Between } \\
2010 \text { and 2014 }\end{array}$ & $\begin{array}{c}\text { Percent Early } \\
\text { Boomers Who } \\
\text { Retired Between } \\
2004 \text { and 2008 }\end{array}$ & $\begin{array}{c}\text { Difference in } \\
\text { Percent Between } \\
\text { Mid Boomers and } \\
\text { Early Boomers }\end{array}$ \\
\hline $\begin{array}{l}\text { HI on Job; No HI in } \\
\text { Retirement in 2010 }\end{array}$ & 3.6 & 6.3 & -2.7 \\
\hline $\begin{array}{l}\text { No HI on Job; No HI in } \\
\text { Retirement in 2010 }\end{array}$ & 2.7 & 4.2 & -1.5 \\
\hline $\begin{array}{l}\text { HI on Job; HI in Retirement in } \\
2010\end{array}$ & 7.6 & 10.2 & -4.2 \\
\hline
\end{tabular}

Sample is conditioned on having held job in base period.

To further analyze the relation between health insurance type and actual retirement between 2010 and 2014, and over the analogous period for an older cohort, Table 11 presents the results of a probit analysis. Here we pool the samples from the Early Boomer and Mid Boomer cohorts 
and observe their retirement behavior from the year they entered the HRS until four years later. The dependent variable is 1 if the individual retired over the four year period, either between 2010 and 2014 for Mid Boomers or 2004 to 2008 for Early Boomers.

The probit coefficients reported in column 1 are for dummy explanatory variables indicating type of health insurance coverage in the base period, and for interaction variables between cohort (Mid Boomer) and indicators of the type of employer provided health insurance. The interaction variables reflect the difference in retirements between the Mid Boomers and the Early Boomer cohort. A dummy variable for cohort is also included separately, but the coefficient is not reported in Table 11. There are no other covariates in the probit underlying column 1.

Those with health insurance on their current job but not in retirement, and those with health insurance both on the job and when retired, are more likely to have retired than those without health insurance either at work or should they retire. This result is consistent with the descriptive statistics in Table 10. However, neither interaction variable is significant. That is, we can find no statistically significant evidence that compared to Early Boomers, Mid Boomers with health insurance on the job, but with no retiree health insurance, were less likely to stay in the labor market as a result of ACA.

As seen from the coefficients reported in column 2, when other covariates are added to the probit underlying column 1 , the findings remain unchanged. The additional covariates are related to demographics, education, health, pension coverage, and unemployment. Thus we find no statistically significant evidence that ACA accelerated the relative retirement rates of those who, before ACA, had health insurance when working, but did not have retiree health insurance. 
Table 11. Probit of Retired in 2008/2014 on Health Insurance Dummy Variable in 2004/2010*

\begin{tabular}{|l|c|c|}
\hline & Includes Only HI Variables & $\begin{array}{c}\text { Includes HI Variables and } \\
\text { Other Covariates }\end{array}$ \\
\hline HI from Current Employer, & 0.1806 & 0.1397 \\
No Retiree HI* & $(.1134)$ & $(.1233)$ \\
\hline HI on Current Job and in & 0.4380 & 0.3484 \\
Retirement & $(.1181)$ & $(.1293)$ \\
\hline MBs-HI from Current & -0.0634 & -0.1372 \\
Employer, No Retiree HI* & $(.1634)$ & $(.1720)$ \\
\hline MBs- HI on Current Job and & 0.0428 & -0.0209 \\
in Retirement & $(.1744)$ & $(.1825)$ \\
\hline Sample Size & \multicolumn{2}{|c|}{3939} \\
\hline
\end{tabular}

*Standard errors are in parentheses. Also included in each probit is a dummy variable indicating no health insurance coverage when working, but coverage when retired. That category includes only 58 observations. Other covariates included in column 2 measure gender, age, education, health, occupation, type of pension coverage and whether the individual is looking for work.

To be sure, the effects of ACA on retirements may have been obscured by major differences in employer behavior between the Early Boomers’ and Mid Boomers’ retirements. It might also be that not enough time has passed to see the basic effect of ACA on retirement. In view of these possibilities, we turn to alternative approaches to estimating the effects of ACA on retirement.

\section{Health Insurance Coverage and Expected Claiming and Retirement Ages}

To set the stage for our analysis of the effects of ACA on retirement in the intermediate term, in Table 12 we report the expected ages of claiming Social Security benefits (or the expected retirement age - the age at which the individual stops work entirely) from 2010 through 2014, and relate those dates to health insurance coverage in $2010 .{ }^{11}$ Consider Table 12, column 1, row

\footnotetext{
${ }^{11}$ The sample in Table 12 is conditioned on the respondent having held a job in all three years. It includes those who answered don't know or refused to the age of claiming or retirement age questions. For those whose claiming age is missing, we use age 62. For those who report a claiming age over 70, we change the claiming age to 70. For those with missing expected retirement age, we use the expected claiming age. Appendix Table 2 reports the claiming and retirement ages for the subsample of respondents who did not answer "don't know” or "refused”
} 
1 , in the top panel. On average respondents with health insurance on the job but not in retirement in 2010 expected, as of 2010, to claim benefits at age 65.0. From column 1, row 2, respondents with no health insurance either on the job or in retirement expected to claim benefits at 64.6. Thus respondents who in 2010 had health insurance on the job, but not in retirement, expected to claim their Social Security benefits 0.4 years later than those with no health insurance on the job, or in retirement. A person with health insurance on the job but not in retirement also expected to claim benefits half a year later than someone with health insurance both on the job and when retired (65.0 vs. 64.5). ${ }^{12}$

The relation of type of health insurance to expected retirement age differed somewhat from the relation of type of health insurance to Social Security claiming age. From the lower panel in Table 12, in 2010, those with health insurance on their current job, but no health insurance in retirement, expected to retire 7 tenths of a year earlier than those with no health insurance either on the job or in retirement (64.5 vs. 65.2). They expected to retire 0.4 years after those with health insurance both at work and in retirement (64.5 vs. 64.1$)$.

Next compare results between the two panels in Table 12, beginning with row 1, column 1 in each panel. Those with health insurance on the job and no health insurance in retirement in 2010 expected to claim their Social Security benefits at age 65, half a year after they retired. Those with no health insurance on the job and no health insurance in retirement expected to claim benefits 0.6 years before they retired, while those with health insurance both on the job and in retirement expected to retire four tenths of a year before they claimed their benefits.

to the expected age questions. The comparisons among cell values are similar, but not identical, to those described in the following paragraphs.

${ }^{12}$ Note that for both the expected age of claiming and of retirement, all medians are age 65 and do not differ by health insurance coverage. 
Table 12: Expected Ages of Social Security Benefit Claiming and Retirement, weighted*

\begin{tabular}{|l|c|c|c|}
\hline & 2010 & 2012 & 2014 \\
\hline \multicolumn{2}{|c|}{ Expected Age of Benefit Claiming } & 65.1 \\
\hline $\begin{array}{l}\text { HI on Job; No HI in Retirement in } \\
2010\end{array}$ & 65.0 & 64.8 & 64.6 \\
\hline $\begin{array}{l}\text { No HI on Job; No HI in Retirement in } \\
2010\end{array}$ & 64.6 & 64.6 & 64.8 \\
\hline $\begin{array}{l}\text { HI on Job; HI in Retirement in 2010 } \\
\text { Expected Age of Retirement }\end{array}$ & 65.0 & 65.2 \\
\hline $\begin{array}{l}\text { HI on Job; No HI in Retirement in } \\
\text { 2010 }\end{array}$ & 64.5 & 65.0 & 65.4 \\
\hline $\begin{array}{l}\text { No HI on Job; No HI in Retirement in } \\
2010\end{array}$ & 65.2 & 65.5 & 64.9 \\
\hline HI on Job; HI in Retirement in 2010 & 64.1 & 64.9 & \\
\hline
\end{tabular}

*2010 weights. Includes only respondents who held a job in all three years.

Next consider the statistics relevant to the effects of ACA on age of benefit claiming or retirement expectations. Compare the expected ages of claiming or retirement in 2010 with the expected ages in 2014. There was little change in the expected age of Social Security benefit claiming. More importantly, the movement in the expected age of retirement is in the opposite direction of what was expected from changes in ACA. If no other influences were operating except for the change in ACA, our expectation is that the expected age of claiming and of retirement should decline for those who had health insurance on the job, but not in retirement. Instead, from the lower panel, first row, between 2010 and 2014, the expected age of retirement increased by seven tenths of a year for those who had health insurance when working, but no retiree health insurance.

To be sure, the increase in retirement age in all categories may reflect an adjustment to capital losses and job losses suffered during the Great Recession. However, the increase in expected retirement age for those with health insurance at work but not in retirement was larger than the increase observed for those who had no employer provided health insurance from their employer while working, or in retirement. 
Clearly the descriptive statistics on changes in expected retirement age conditional on initial health insurance coverage are not sufficient to test the underlying effects of health insurance availability on retirement. There are many considerations beyond the availability of health insurance that drive the claiming and retirement decisions. If these are systematically related to the availability of health insurance on the job and/or in retirement in 2010, we will not observe the expected relationship between health insurance and retirement in simple descriptive statistics. To isolate the effects of health insurance availability at work and in retirement on retirement outcomes, it will be necessary to take account of the role of pensions and other covariates that are correlated with the availability of health insurance and are also correlated with retirement outcomes. Accordingly, we turn to multivariate regressions of changes in expected retirement age on initial health insurance coverage.

The sample underlying Table 13 includes members of both the Early and Mid Boomer cohorts. It is restricted to those who reported a claiming or retirement age in the initial and final year, either 2004 and 2008 for the Early Boomers, or 2010 and 2014 for the Mid Boomers. To be included, the respondents could not have answered “don't know" or "refuse” when asked about their expectation. Table 13 is also restricted to respondents who in the initial year they were in the survey reported they expected to claim benefits or retire at ages 65 or earlier, since ACA only affects availability of health insurance when retired for those under 65 . The first two columns in Table 13 report results for regressions with the claiming age as the dependent variable. The next two columns report results where expected retirement age is the dependent variable.

In all cases, the key independent variable is the coefficient reported in row 3, the coefficient on a dummy variable indicating that the individual had health insurance at work but not in retirement, interacted with an indicator that he or she was a member of the Mid Boomer cohort. 
For purposes of difference-in-difference analysis, other health insurance dummy variables in all regressions include an indicator of coverage on the job but not in retirement, an indicator of coverage both on the job and in retirement, and an interaction between coverage on the job and in retirement with an indicator the individual is from the Mid Boomer cohort. Those with no health insurance while employed and with no retiree health insurance fall within the excluded category. The multiple regressions in columns 2 and 4 also include variables measuring gender, age, a series of dummy variables measuring schooling, education, health, occupation and type of pension coverage.

The fits for all regressions are very poor. The coefficients reported in row 3, columns 3 and 4 are in the wrong direction, suggesting that compared to those with no health insurance on the job or in retirement, ACA would increase the expected retirement date for those with health insurance on the job but not in retirement. This small effect is not statistically significant, however. The coefficients in the regressions for expected claiming age are very near zero and also are not statistically significant.

The bottom line is that there is no statistically significant evidence that ACA has affected retirement intentions.

Once again, it is possible that too short a time has passed for ACA to have affected retirement expectations, especially since many in the sample would have been a number of years away from retirement, even in 2014. Reoptimization may take time, and not enough time may have passed for plans to have been fully readjusted. 
Table 13. Change in Expected Dates of Claiming and Retirement for Early and Mid Boomers (Sample restricted to those who reported expected claiming or retirement age of 65 or below.)

\begin{tabular}{|c|c|c|c|c|}
\hline & \multicolumn{2}{|c|}{$\begin{array}{l}\text { Dependent Variable: Change in } \\
\text { Expected Claiming Date* }\end{array}$} & \multicolumn{2}{|c|}{$\begin{array}{l}\text { Dependent Variable: Change in } \\
\text { Expected Retirement Date* }\end{array}$} \\
\hline & $\begin{array}{l}\text { Includes Only HI } \\
\text { Variables }\end{array}$ & $\begin{array}{l}\text { Includes HI and } \\
\text { Other Covariates }\end{array}$ & $\begin{array}{l}\text { Includes Only HI } \\
\text { Variables }\end{array}$ & $\begin{array}{l}\text { Includes HI and } \\
\text { Other Covariates }\end{array}$ \\
\hline $\begin{array}{l}\text { HI from Current } \\
\text { Employer, No } \\
\text { Retiree HI** }\end{array}$ & $\begin{array}{c}0.144 \\
(.61)\end{array}$ & $\begin{array}{c}0.088 \\
(.37)\end{array}$ & $\begin{array}{l}-0.790 \\
(2.14)\end{array}$ & $\begin{array}{l}-0.617 \\
(1.64)\end{array}$ \\
\hline $\begin{array}{l}\text { HI on Current Job } \\
\text { and in } \\
\text { Retirement** }\end{array}$ & $\begin{array}{l}0.221 \\
(.81)\end{array}$ & $\begin{array}{l}0.124 \\
(.44)\end{array}$ & $\begin{array}{l}-0.933 \\
(2.18)\end{array}$ & $\begin{array}{l}-0.796 \\
(1.82)\end{array}$ \\
\hline $\begin{array}{l}\text { MBs-HI from } \\
\text { Current Employer, } \\
\text { No Retiree HI** }\end{array}$ & $\begin{array}{l}-0.115 \\
(.37)\end{array}$ & $\begin{array}{l}-0.150 \\
(.48)\end{array}$ & $\begin{array}{l}0.614 \\
(1.28)\end{array}$ & $\begin{array}{l}0.536 \\
(1.10)\end{array}$ \\
\hline $\begin{array}{l}\text { MBs- HI on } \\
\text { Current Job and in } \\
\text { Retirement** }\end{array}$ & $\begin{array}{l}0.181 \\
(.50)\end{array}$ & $\begin{array}{l}0.182 \\
(.50)\end{array}$ & $\begin{array}{l}1.150 \\
(2.01)\end{array}$ & $\begin{array}{l}1.184 \\
(2.05)\end{array}$ \\
\hline R square & 0.0091 & 0.0267 & 0.0055 & 0.0196 \\
\hline Sample Size & & & & \\
\hline
\end{tabular}

$\mathrm{t}$ values are in parentheses.

*Covariates include variables measuring gender, age, a series of dummy variables measuring schooling, education, health, occupation and type of pension coverage.

**The omitted category is no health insurance on the current job and no retiree health insurance.

It is also possible that the new incentives are not yet fully understood. Learning may take time, or the time period may be too short to allow other adjustments, such as the additional saving required if retirement is to be accelerated. Or as the dynamics of health insurance coverage examined in Section II suggest, the specification of the expected retirement date equation may be too simple. When we allow for other sources of health insurance coverage, type of employer provided health insurance in 2010 may be an imperfect measure of the incentive facing some individuals. This error in measurement may obscure a true effect of ACA on retirement. 
To further investigate the reasons for this finding in the intermediate term, we now turn to an analysis of a structural model that has been useful in explaining various discontinuities in the retirement hazard, and the relation of nonlinear retirement incentives to retirement outcomes.

IV. A Simulation Analysis Based on a Structural Model

Our structural analysis simulates the effects of the Affordable Care Act on retirement. The simulations are based on a model we developed under a grant from the National Institute on Aging (Gustman and Steinmeier, forthcoming). The model is dynamic. Life expectancy and health are stochastic.

There is considerable heterogeneity built into the utility function. Time preference and preference for leisure over work differ among individuals. Although time preference varies among individuals, time preference is assumed to be constant over time for any individual. Leisure preferences can change after retirement, possibly inducing some individuals to return to work after an initial period of retirement.

The budget equation includes earnings in full and part-time employment, detailed specification of formulas governing employer provided pension plans, Social Security benefit rules, health insurance and health expenditures, and spouse's income. Because the analysis explicitly models the incentives from defined benefit pensions, it avoids a fundamental mistake of studies that focus on retiree health insurance, but ignore or mismeasure the accrual profiles of each individual's DB pension. Typically such studies attribute some of the (omitted) effects of DB pensions on retirement to retiree health insurance.

An important simplification in this model concerns the relation between Social Security benefit claiming and retirement. Here we impose the assumption that Social Security benefits are 
claimed as soon as possible. For a study that allows the claiming date to vary and also allows the retirement date to differ from the claiming date, see Gustman and Steinmeier (2015).

A point of emphasis is the relationship between detailed health outcomes, health risks, wealth and retirement. The health section of the model includes several individual health behaviors, such as smoking, drinking, and obesity, as well as the effects of several medical conditions, such as diabetes, heart problems, and lung problems. These help to determine the health status of an individual, which can change over time. The health status, in conjunction with the individual's insurance status, determines the distribution of out-of-pocket health costs.

Within this framework, individuals make labor force choices and savings choices to maximize expected utility over time. Maximization of utility, subject to the budget constraint over the life cycle, governs the retirement decision and the decision to increase work effort once retired.

The estimated effects of ACA are only approximated. We begin the simulation by modifying the budget constraint to reflect the situation just before the adoption of ACA. We then simulate the effects of the changing availability of health insurance due to ACA by assuming full subsidization of health insurance expenditures through ACA. We then compare outcomes before and after ACA, where the opportunity set is gleaned from our descriptive analysis, and the changes fostered by the ACA are modeled both in the short term and in the long term. Note that this approximation will exaggerate the reduction in the work incentive for higher income individuals who are not eligible for a subsidy under ACA while employed. It will also exaggerate the reduction in work incentives if ACA is inferior to employer provided health insurance. We find only a small effect of ACA on retirement even after standardizing for income group. 
The model was estimated for individuals in the original Health and Retirement Study cohort, ages 51 to 61 in 1992. These individuals are now in their seventies and eighties, well past retirement age. To make the simulations more relevant to individuals currently on the cusp of retirement, several changes have been made to the budget sets for the individuals in the sample. First, the full retirement age for Social Security has been set to 66. For most of the individuals in the original HRS cohort the full retirement age was 65 , but for individual currently retiring it is 66. For the same reason, the value of the delayed retirement credit has been adjusted to $8 \%$ for the entire sample; it was considerably less for most of the members of the original HRS cohort. Thirdly, the earnings test has been eliminated for individuals above the full retirement age, reflecting a change in the law in 2001. Finally, for individuals who had only a defined benefit pension, $43 \%$ of them were randomly reassigned to have a defined contribution pension. This roughly reflects the change in the pension environment between the original HRS cohort and the more recent Early and Mid Boomer cohorts who are currently in the age range where they are making retirement decisions.

The results of the base simulation, which omit the effects of the Affordable Care Act, are shown in Tables 14 through 16. The last two columns at the top of Table 14 give the simulated percentages of individuals who are retired from full-time work and who are fully retired, by age. The first two columns in the top part of the table give the increase in the percentages of individuals in the associated retirement state. For instance, at age $61,48.6 \%$ of the individuals are simulated to be retired from full-time work, and at age $62,64.7 \%$ are simulated to be retired. The difference, $16.1 \%$, is the net increase in the number of individuals retired from full-time work. It is the net flow of individuals who are newly retired from full-time work less the individuals who were not working full-time at age 61 but have returned to full-time work at age 
62. The bottom of the table indicates the hazard rates for retiring at the indicate ages. As expected, the hazard rate has a sharp peak at age 62, the Social Security early entitlement age, and a secondary peak at age 65, the Medicare eligibility age.

Table 15 breaks down the percentage of individuals working full-time, part-time, and not working at all by lifetime income status. To do so, we calculated the potential lifetime income from the Social Security records and divided the sample roughly into thirds. The lower income groups are simulated to have much higher rates of part-time work, probably because the wage penalty for part-time work vs. full-time work is not nearly as severe for lower wage workers. Conversely, higher income individuals are much less likely to be in part-time work, implying that they have a much greater probability of moving from full-time work to full retirement.

Table 16 is similar to Table 15, except that here the breakdown is by current health status rather than lifetime income group. Health status is derived from a combination of mobility limitations, pain levels, activity of daily living (ADL) limitations, and self-assessed overall health. Fair health is generally associated with one or two mobility limitations, while poor health is associated with several mobility limitations but none or one ADL limitation. "Terrible" health is associated with multiple ADL limitations. As expected, the worse the health status, the lower is the percentage of full-time work and the higher is the percentage of full retirement. The difference between the good and fair health states is not as dramatic as the difference between fair and poor health, or between poor and terrible health. 
Table 14

Retirement Percentages in Base Line Simulation

\section{Retirement \\ from Full \\ Time Work Retirement \\ Percentage Retiring at Indicated Age}

54

55

56

57

58

59

60

61

62

63

64

65

66

67

54

55

56

57

58

59

60

61

62

63

64

65

66

67

\section{7}

3.3

3.1

3.7

4.0

4.1

5.4

4.2

16.1

1.8

5.8

5.2

2.4

4.3
1.9

2.8

2.5

2.9

3.5

3.9

4.6

3.6

10.3

1.2

5.3

4.8

2.6

4.4
Retirement Hazards at Indicated Age

$\begin{array}{lll}54 & 3.3 & 2.2 \\ 55 & 4.2 & 3.3 \\ 56 & 4.1 & 3.1 \\ 57 & 5.1 & 3.7 \\ 58 & 5.8 & 4.6 \\ 59 & 6.3 & 5.4 \\ 60 & 8.9 & 6.7 \\ 61 & 7.5 & 5.6 \\ 62 & 31.3 & 17.0 \\ 63 & 5.1 & 2.4 \\ 64 & 17.3 & 10.8 \\ 65 & 18.8 & 11.0 \\ 66 & 10.7 & 6.7 \\ 67 & 21.3 & 12.1\end{array}$

Retirement from Full

Time Work Retirement

Percentage Retired at Indicate Age

$\begin{array}{ll}20.7 & 15.5 \\ 24.0 & 18.3 \\ 27.1 & 20.8 \\ 30.8 & 23.7 \\ 34.8 & 27.2 \\ 39.0 & 31.1 \\ 44.3 & 35.7 \\ 48.6 & 39.4 \\ 64.7 & 49.7 \\ 66.5 & 50.9 \\ 72.3 & 56.2 \\ 77.5 & 61.0 \\ 79.8 & 63.6 \\ 84.2 & 68.0\end{array}$

20.7

15.5

18.3

20.8

23.7

27.2

35.7

39.4

49.7

50.9

56.2

61.0

63.6

68.0 
Table 15

Percentage in Each Retirement Status by Income Group

in the Base Simulation

\begin{tabular}{|c|c|c|c|c|c|c|}
\hline \multirow[b]{2}{*}{ Age } & \multicolumn{6}{|c|}{ Income Group } \\
\hline & Low & Middle & High & Low & Middle & High \\
\hline \multicolumn{4}{|c|}{ Full-Time Work } & \multicolumn{3}{|c|}{ Part-Time Work } \\
\hline 54 & 77.9 & 80.3 & 79.5 & 6.5 & 5.1 & 4.2 \\
\hline 55 & 76.4 & 75.6 & 76.0 & 6.9 & 5.8 & 4.8 \\
\hline 56 & 73.1 & 73.0 & 72.5 & 7.2 & 6.5 & 5.4 \\
\hline 57 & 70.5 & 68.6 & 68.4 & 7.9 & 7.3 & 6.4 \\
\hline 58 & 67.1 & 64.2 & 64.4 & 8.4 & 7.9 & 6.6 \\
\hline 59 & 64.3 & 60.1 & 59.1 & 8.4 & 8.1 & 7.0 \\
\hline 60 & 59.8 & 54.7 & 52.9 & 9.2 & 9.2 & 7.5 \\
\hline 61 & 57.2 & 50.4 & 47.7 & 9.6 & 9.9 & 8.2 \\
\hline 62 & 31.1 & 35.9 & 38.8 & 26.3 & 11.6 & 8.1 \\
\hline 63 & 28.5 & 35.3 & 36.6 & 26.8 & 11.9 & 9.1 \\
\hline 64 & 23.9 & 29.0 & 30.0 & 26.8 & 13.0 & 9.6 \\
\hline 65 & 19.4 & 23.3 & 24.8 & 27.0 & 13.8 & 9.8 \\
\hline 66 & 19.1 & 21.1 & 20.3 & 25.2 & 14.0 & 10.7 \\
\hline 67 & 14.7 & 16.4 & 16.3 & 25.3 & 14.0 & 10.6 \\
\hline
\end{tabular}

Full Retirement

$\begin{array}{llll}54 & 15.6 & 14.6 & 16.3 \\ 55 & 16.7 & 18.6 & 19.2 \\ 56 & 19.7 & 20.5 & 22.1 \\ 57 & 21.6 & 24.1 & 25.2 \\ 58 & 24.5 & 27.9 & 29.0 \\ 59 & 27.3 & 31.8 & 33.9 \\ 60 & 31.0 & 36.1 & 39.6 \\ 61 & 33.2 & 39.7 & 44.1 \\ 62 & 42.6 & 52.5 & 53.1 \\ 63 & 44.7 & 52.8 & 54.3 \\ 64 & 49.3 & 58.0 & 60.4 \\ 65 & 53.6 & 62.9 & 65.4 \\ 66 & 55.7 & 64.9 & 69.0 \\ 67 & 60.0 & 69.6 & 73.1\end{array}$


Table 16

Percentage in Each Retirement Status by Health Group in the Base Simulation

\begin{tabular}{|c|c|c|c|c|c|c|c|c|}
\hline \multirow[b]{2}{*}{ Age } & \multicolumn{8}{|c|}{ Health Status } \\
\hline & Good & Fair & Poor & Terrible & Good & Fair & Poor & Terrible \\
\hline & \multicolumn{4}{|c|}{ Percent Working Full-Time } & \multicolumn{4}{|c|}{ Percent Working Part-Time } \\
\hline 54 & 84.1 & 81.2 & 65.7 & 43.5 & 4.5 & 5.1 & 7.3 & 8.6 \\
\hline 55 & 81.4 & 78.2 & 60.7 & 37.2 & 5.1 & 5.6 & 7.8 & 8.8 \\
\hline 56 & 78.8 & 75.4 & 57.0 & 32.5 & 5.7 & 6.2 & 8.0 & 8.9 \\
\hline 57 & 75.5 & 72.0 & 52.2 & 27.5 & 6.6 & 7.0 & 8.9 & 9.4 \\
\hline 58 & 72.0 & 68.1 & 47.6 & 22.9 & 7.0 & 7.5 & 9.2 & 9.8 \\
\hline 59 & 68.4 & 64.1 & 42.5 & 18.3 & 7.2 & 7.8 & 9.5 & 9.8 \\
\hline 60 & 63.4 & 59.0 & 36.4 & 13.6 & 8.0 & 8.5 & 10.2 & 10.1 \\
\hline 61 & 59.5 & 55.0 & 31.9 & 10.4 & 8.6 & 9.1 & 10.8 & 10.6 \\
\hline 62 & 43.4 & 37.6 & 16.7 & 4.1 & 14.9 & 16.0 & 14.9 & 9.1 \\
\hline 63 & 41.8 & 35.9 & 15.1 & 3.2 & 15.7 & 16.8 & 15.3 & 8.7 \\
\hline 64 & 35.5 & 30.0 & 11.2 & 2.1 & 16.4 & 17.5 & 14.8 & 7.7 \\
\hline 65 & 29.5 & 24.6 & 8.1 & 1.5 & 17.3 & 18.1 & 14.2 & 6.8 \\
\hline 66 & 26.7 & 22.6 & 6.5 & 0.9 & 17.1 & 17.8 & 14.5 & 7.3 \\
\hline 67 & 21.6 & 17.8 & 4.5 & 0.6 & 17.4 & 18.0 & 13.8 & 6.6 \\
\hline
\end{tabular}

Percent Completely Retired

$\begin{array}{lllll}54 & 11.4 & 13.7 & 27.0 & 47.9 \\ 55 & 13.5 & 16.2 & 31.5 & 54.0 \\ 56 & 15.5 & 18.4 & 35.0 & 58.6 \\ 57 & 17.9 & 21.0 & 38.9 & 63.1 \\ 58 & 21.0 & 24.4 & 43.2 & 67.3 \\ 59 & 24.4 & 28.1 & 48.0 & 71.9 \\ 60 & 28.6 & 32.5 & 53.4 & 76.3 \\ 61 & 31.9 & 35.9 & 57.3 & 79.0 \\ 62 & 41.7 & 46.4 & 68.4 & 86.8 \\ 63 & 42.5 & 47.3 & 69.6 & 88.1 \\ 64 & 48.1 & 52.5 & 74.0 & 90.2 \\ 65 & 53.2 & 57.3 & 77.7 & 91.7 \\ 66 & 56.2 & 59.6 & 79.0 & 91.8 \\ 67 & 61.0 & 64.2 & 81.7 & 92.8\end{array}$


Table 17 begins the exploration of the effects of introducing the Affordable Care Act (ACA). As discussed in the descriptive analysis, there are basically three groups that are relevant to the ACA. The first group is those who have no insurance on their current job and therefore no insurance in retirement. This group is simulated to have insurance after the ACA is introduced, and in the model this means that their medical costs are largely eliminated relative to the base simulation. The second group is those who have insurance on the job but no retiree health coverage. This is the group that is subject to the situation frequently called "job lock," where they feel that they have to keep on working in order to keep their insurance. As noted previously, one would expect to find the largest effect of the ACA on this group, since after the introduction of the ACA this group will no longer feel that they have to continue working in order to keep health insurance. The third group is those who have health insurance in their job, and this insurance will continue when they are retired up to the Medicare eligibility age. The ACA will have only a small if any effect on the retirement behavior of this group.

Table 17 relates to full-time work by individuals who have insurance in their job but no retiree insurance, that is, the individuals subject to job lock. The columns of the table pertain to the age at which the ACA is introduced. The first column pertains to the situation when the ACA is introduced at age 25 . Since the simulations start at age 25 , this simulation corresponds to the effects of a fully anticipated ACA over the full lifetime. The next three columns suppose that the individuals are 50, 55, and 60 at the time the ACA is introduced. Prior to those ages, the individuals have not anticipated the ACA and had made labor force and savings decisions as though there would be no ACA. After the introduction of the ACA, the individuals reoptimize their decisions, given the labor force and savings decisions they have made up to that point. 
Columns for ages after 60 are not included, since at age 65 Medicare becomes available and the ACA essentially becomes irrelevant.

The figures in Table 17 are the percentages of individuals retired from full-time work in the relevant simulation with ACA minus the percentage of individuals retired from full-time work in the base simulation, in which there was no ACA. For instance, the figure of 0.7 in the third column of the row for age 62 indicates that in the simulation for the introduction of the ACA at age 55, retirement from full-time work at age 62 was 0.7 percentage point higher than the corresponding percentage in the base simulation. In general, these percentages are relatively low, but even more interesting for the present research is that these percentages do not move much as one goes across the columns. That is, the effect of the ACA at a particular age does not change very much regardless of whether it was introduced two years ago or twenty years ago, or whether it has always been there.

This last result is perhaps a bit surprising, so it may be useful to ask what might be generating it. The answer appears to be in the response of saving to the relatively small probability of encountering high health costs before age 65, when Medicare kicks in. Another way to ask the question is to think about how much of saving is attributable to the prospect of having high medical expenses before age 65. Since the probability of these expenses is fairly small, the answer is probably not much. In response to the possibility of realizing these expenses, there are two possible outcomes. One is to accumulate resources before the expenses, and the other is to adjust consumption after the expenses. These results seem to indicate the latter, that is, cumulative saving is probably not that much different, especially relative to retirement saving, whether or not ACA has been around for a long time. 
Table 17

Percentage Point Increase in Retirement from Full-Time Work Due to Introduction of ACA for Sample Originally with Insurance While Working But No Retiree Coverage

\begin{tabular}{|c|c|c|c|c|c|c|c|c|}
\hline \multirow[b]{2}{*}{ Age } & \multicolumn{8}{|c|}{ ACA Introduction Age } \\
\hline & 25 & 50 & 55 & 60 & 25 & 50 & 55 & 60 \\
\hline \multicolumn{5}{|c|}{ All Income Groups } & \multicolumn{4}{|c|}{ Low Income Group } \\
\hline 54 & 0.4 & 0.4 & 0.0 & 0.0 & 0.7 & 0.7 & 0.0 & 0.0 \\
\hline 55 & 0.3 & 0.3 & 0.1 & 0.0 & 0.5 & 0.5 & 0.1 & 0.0 \\
\hline 56 & 0.3 & 0.3 & 0.2 & 0.0 & 0.5 & 0.5 & 0.1 & 0.0 \\
\hline 57 & 0.4 & 0.4 & 0.2 & 0.0 & 0.5 & 0.6 & 0.2 & 0.0 \\
\hline 58 & 0.3 & 0.3 & 0.3 & 0.0 & 0.3 & 0.3 & 0.2 & 0.0 \\
\hline 59 & 0.4 & 0.4 & 0.3 & 0.0 & 0.4 & 0.4 & 0.3 & 0.0 \\
\hline 60 & 0.5 & 0.5 & 0.5 & 0.4 & 0.4 & 0.5 & 0.4 & 0.2 \\
\hline 61 & 0.4 & 0.5 & 0.5 & 0.4 & 0.2 & 0.3 & 0.3 & 0.3 \\
\hline 62 & 0.6 & 0.7 & 0.7 & 0.6 & 0.6 & 0.7 & 0.7 & 0.6 \\
\hline 63 & 0.4 & 0.5 & 0.5 & 0.5 & 0.4 & 0.5 & 0.6 & 0.5 \\
\hline 64 & 0.4 & 0.5 & 0.5 & 0.5 & 0.6 & 0.7 & 0.8 & 0.7 \\
\hline 65 & 0.3 & 0.4 & 0.4 & 0.4 & 0.2 & 0.3 & 0.4 & 0.3 \\
\hline 66 & -0.1 & 0.0 & 0.1 & 0.1 & 0.0 & 0.1 & 0.2 & 0.1 \\
\hline 67 & 0.0 & 0.1 & 0.1 & 0.1 & 0.0 & 0.1 & 0.2 & 0.1 \\
\hline
\end{tabular}

Middle Income Group

High Income Group

$\begin{array}{lllllllll}54 & 0.4 & 0.4 & 0.0 & 0.0 & 0.2 & 0.2 & 0.0 & 0.0 \\ 55 & 0.3 & 0.3 & 0.0 & 0.0 & 0.2 & 0.2 & 0.2 & 0.0 \\ 56 & 0.3 & 0.3 & 0.2 & 0.0 & 0.2 & 0.2 & 0.2 & 0.0 \\ 57 & 0.3 & 0.3 & 0.3 & 0.0 & 0.3 & 0.3 & 0.3 & 0.0 \\ 58 & 0.4 & 0.4 & 0.4 & 0.0 & 0.4 & 0.4 & 0.4 & 0.0 \\ 59 & 0.5 & 0.5 & 0.5 & 0.0 & 0.4 & 0.5 & 0.5 & 0.0 \\ 60 & 0.7 & 0.7 & 0.7 & 0.6 & 0.5 & 0.6 & 0.6 & 0.6 \\ 61 & 0.6 & 0.6 & 0.6 & 0.6 & 0.4 & 0.5 & 0.5 & 0.4 \\ 62 & 0.7 & 0.8 & 0.7 & 0.7 & 0.3 & 0.4 & 0.4 & 0.4 \\ 63 & 0.7 & 0.7 & 0.7 & 0.7 & 0.3 & 0.4 & 0.4 & 0.4 \\ 64 & 0.5 & 0.6 & 0.5 & 0.5 & 0.2 & 0.3 & 0.4 & 0.4 \\ 65 & 0.4 & 0.4 & 0.4 & 0.4 & 0.2 & 0.3 & 0.3 & 0.3 \\ 66 & 0.0 & 0.0 & 0.1 & 0.1 & 0.0 & 0.1 & 0.1 & 0.1 \\ 67 & 0.0 & 0.1 & 0.1 & 0.1 & 0.0 & 0.1 & 0.1 & 0.1\end{array}$


Table 17 (continued)

Percentage Point Increase in Retirement from Full-Time Work Due to Introduction of ACA for Sample Originally with Insurance While Working But No Retiree Coverage

\begin{tabular}{|c|c|c|c|c|c|c|c|c|}
\hline & & & & & Age & & & \\
\hline Age & 25 & 50 & 55 & 60 & 25 & 50 & 55 & 60 \\
\hline & & $\mathrm{d} \mathrm{He}$ & $\mathrm{h} G \mathrm{r}$ & & & or $\mathrm{He}$ & h Gr & \\
\hline 54 & 0.3 & 0.3 & 0.0 & 0.0 & 0.6 & 0.6 & 0.0 & 0.0 \\
\hline 55 & 0.3 & 0.3 & 0.1 & 0.0 & 0.5 & 0.5 & 0.3 & 0.0 \\
\hline 56 & 0.3 & 0.3 & 0.1 & 0.0 & 0.6 & 0.7 & 0.5 & 0.0 \\
\hline 57 & 0.3 & 0.3 & 0.1 & 0.0 & 0.5 & 0.6 & 0.5 & 0.0 \\
\hline 58 & 0.3 & 0.3 & 0.2 & 0.0 & 0.5 & 0.6 & 0.6 & 0.0 \\
\hline 59 & 0.4 & 0.4 & 0.3 & 0.0 & 0.5 & 0.6 & 0.6 & 0.0 \\
\hline 60 & 0.6 & 0.6 & 0.5 & 0.4 & 0.4 & 0.5 & 0.6 & 0.5 \\
\hline 61 & 0.5 & 0.6 & 0.5 & 0.4 & 0.3 & 0.4 & 0.5 & 0.5 \\
\hline 62 & 0.5 & 0.6 & 0.6 & 0.5 & 0.7 & 0.7 & 0.8 & 0.8 \\
\hline 63 & 0.5 & 0.5 & 0.5 & 0.5 & 0.5 & 0.5 & 0.6 & 0.6 \\
\hline 64 & 0.5 & 0.5 & 0.5 & 0.5 & 0.4 & 0.5 & 0.6 & 0.6 \\
\hline 65 & 0.2 & 0.3 & 0.3 & 0.3 & 0.2 & 0.3 & 0.3 & 0.3 \\
\hline 66 & 0.0 & 0.1 & 0.1 & 0.1 & 0.0 & 0.0 & 0.1 & 0.1 \\
\hline 67 & 0.0 & 0.1 & 0.1 & 0.1 & 0.0 & 0.1 & 0.1 & 0.1 \\
\hline
\end{tabular}


This does not imply that ACA has no effect on retirement. The ACA has some wealth effect because it offsets some of the potential future expenses, and it also makes the value of current employment somewhat less for individuals currently covered in their jobs but not as retirees, since with ACA they would be covered anyway even if retired. Both of these effects reduce incentives for full-time work, which is what the table suggests. But if the effect is coming from these considerations and not from accumulated savings, then the magnitude of the effect will not depend very much on the length of time since the ACA was introduced.

The first panel in the table deals with the overall sample of those with insurance while working but without retiree health insurance, while the next three panels deal with the three income groups within this overall sample. One might expect individuals in the lowest income group to have the largest effect, but this does not seem to be the case. One explanation is that individuals with low incomes are more likely to have little savings, and if high medical expenses arise they fall back on the safety net (Hubbard, Skinner and Zeldes, 1995), which for the purposes of these simulations takes the form of a minimum consumption standard. The middle income group is less likely to follow this route, so their response to the ACA is a bit more pronounced. For the high income group, on the other hand, medical expenses (which are assumed to be dependent on health status but not on income) are a smaller percentage of income, and hence the responses will be more muted.

The last two panels of the table deal with the responses of those in good health and those in poor health, respectively. One might expect the group in poor health to be more responsive to the introduction of the ACA, and that does indeed seem to be the case. Individuals in poor health face higher medical expenses and would be more reluctant to give up full-time jobs and expose themselves to these expenses without the ACA. With the ACA, however, this disincentive to 
retire disappears, and they are therefore more likely to increase their retirement rates relative to those with lower medical expenses. Even here, though, the effect is not large.

Table 18 looks at increases in retirement from full-time work for the sample whose individuals are not covered by health insurance either in their job or in retirement, that is, for those who are not covered at all in the absence of the ACA. In these simulations, a rather unexpected pattern emerges: with the ACA, these individuals are simulated to reduce retirement from full-time work before about age 62 but increase it thereafter. That is, before age 62 they actually increase full-time work in the presence of the ACA.

One explanation for this pattern relies on the fact that the bulk of individuals with no insurance on their full-time jobs are relatively low wage workers with relatively little, if any, savings. If they leave work before age 62, the Social Security early entitlement age, their alternative may be to rely on the minimum consumption standard, in which case their medical expenses are effectively covered. If they work, however, they must pay their medical expenses out of their earnings, which effectively reduces their compensation from which they can purchase other consumption goods. In essence, for this group, they are insured if they leave their full-time jobs but not if they remain in their jobs. Introducing the ACA reduces the medical expenses they incur if they remain in their jobs and hence effectively increases their compensation, which in turn induces them to increase their full-time work. 
Table 18

Percentage Point Increase in Retirement from Full-Time Work for Sample with No Insurance Coverage

\begin{tabular}{|c|c|c|c|c|c|c|c|c|}
\hline \multirow[b]{2}{*}{ Age } & \multicolumn{8}{|c|}{ ACA Introduction Age } \\
\hline & 25 & 50 & 55 & 60 & 25 & 50 & 55 & 60 \\
\hline \multicolumn{5}{|c|}{ All Income Groups } & \multicolumn{4}{|c|}{ Low Income Group } \\
\hline 54 & -0.4 & -0.3 & 0.0 & 0.0 & -0.2 & -0.1 & 0.0 & 0.0 \\
\hline 55 & -0.4 & -0.2 & -0.2 & 0.0 & -0.2 & 0.0 & 0.0 & 0.0 \\
\hline 56 & -0.4 & -0.2 & -0.2 & 0.0 & -0.4 & -0.2 & -0.2 & 0.0 \\
\hline 57 & -0.4 & -0.2 & -0.2 & 0.0 & -0.3 & -0.1 & -0.1 & 0.0 \\
\hline 58 & -0.4 & -0.2 & -0.2 & 0.0 & -0.3 & -0.1 & 0.0 & 0.0 \\
\hline 59 & -0.5 & -0.3 & -0.2 & 0.0 & -0.5 & -0.2 & -0.2 & 0.0 \\
\hline 60 & -0.5 & -0.3 & -0.3 & -0.4 & -0.5 & -0.2 & -0.2 & -0.3 \\
\hline 61 & -0.4 & -0.1 & -0.1 & -0.2 & -0.4 & -0.1 & -0.1 & -0.1 \\
\hline 62 & -0.2 & 0.0 & 0.0 & -0.1 & -0.2 & 0.1 & 0.0 & 0.0 \\
\hline 63 & -0.2 & 0.0 & 0.0 & -0.1 & -0.1 & 0.1 & 0.1 & 0.0 \\
\hline 64 & 0.0 & 0.2 & 0.1 & 0.1 & 0.0 & 0.2 & 0.2 & 0.1 \\
\hline 65 & 0.2 & 0.4 & 0.4 & 0.3 & 0.1 & 0.3 & 0.3 & 0.2 \\
\hline 66 & 0.1 & 0.3 & 0.3 & 0.2 & 0.1 & 0.3 & 0.3 & 0.2 \\
\hline 67 & 0.1 & 0.3 & 0.2 & 0.2 & 0.1 & 0.3 & 0.3 & 0.2 \\
\hline
\end{tabular}

Middle Income Group

High Income Group

$\begin{array}{rrrrrrrrr}54 & -1.0 & -0.9 & 0.0 & 0.0 & -0.6 & -0.4 & 0.0 & 0.0 \\ 55 & -1.0 & -0.9 & -0.6 & 0.0 & -0.3 & -0.2 & -0.2 & 0.0 \\ 56 & -0.8 & -0.7 & -0.5 & 0.0 & -0.3 & -0.1 & -0.1 & 0.0 \\ 57 & -1.1 & -0.9 & -0.8 & 0.0 & -0.3 & -0.1 & -0.1 & 0.0 \\ 58 & -0.9 & -0.8 & -0.7 & 0.0 & -0.2 & 0.0 & -0.1 & 0.0 \\ 59 & -0.9 & -0.7 & -0.7 & 0.0 & -0.1 & 0.0 & 0.0 & 0.0 \\ 60 & -0.8 & -0.6 & -0.6 & -0.7 & 0.0 & 0.1 & 0.1 & -0.1 \\ 61 & -0.5 & -0.3 & -0.3 & -0.4 & -0.1 & 0.0 & 0.0 & -0.1 \\ 62 & 0.0 & 0.2 & 0.2 & 0.1 & -0.1 & 0.0 & 0.0 & -0.1 \\ 63 & -0.1 & 0.0 & 0.0 & -0.1 & -0.3 & -0.1 & -0.2 & -0.2 \\ 64 & 0.1 & 0.2 & 0.2 & 0.1 & 0.0 & 0.1 & 0.1 & 0.0 \\ 65 & 0.3 & 0.5 & 0.5 & 0.4 & 0.3 & 0.5 & 0.5 & 0.4 \\ 66 & 0.2 & 0.4 & 0.3 & 0.2 & 0.1 & 0.3 & 0.2 & 0.2 \\ 67 & 0.2 & 0.3 & 0.3 & 0.2 & 0.1 & 0.2 & 0.2 & 0.1\end{array}$


Table 18 (continued)

Percentage Point Increase in Retirement from Full-Time Work for Sample with No Insurance Coverage

\begin{tabular}{|c|c|c|c|c|c|c|c|c|}
\hline \multirow[b]{2}{*}{ Age } & \multirow[b]{2}{*}{25} & \multicolumn{7}{|c|}{ ACA Introduction Age } \\
\hline & & 50 & 55 & 60 & 25 & 50 & 55 & 60 \\
\hline \multicolumn{5}{|c|}{ Good Health Group } & \multicolumn{4}{|c|}{ Poor Health Group } \\
\hline 54 & -0.4 & -0.3 & 0.0 & 0.0 & -0.5 & -0.3 & 0.0 & 0.0 \\
\hline 55 & -0.4 & -0.3 & -0.2 & 0.0 & -0.4 & -0.1 & -0.2 & 0.0 \\
\hline 56 & -0.5 & -0.3 & -0.3 & 0.0 & -0.3 & 0.0 & 0.0 & 0.0 \\
\hline 57 & -0.5 & -0.3 & -0.3 & 0.0 & -0.2 & 0.0 & 0.0 & 0.0 \\
\hline 58 & -0.4 & -0.2 & -0.2 & 0.0 & -0.3 & -0.1 & -0.1 & 0.0 \\
\hline 59 & -0.6 & -0.4 & -0.3 & 0.0 & -0.3 & 0.0 & 0.0 & 0.0 \\
\hline 60 & -0.5 & -0.3 & -0.2 & -0.4 & -0.4 & -0.1 & -0.1 & -0.3 \\
\hline 61 & -0.5 & -0.3 & -0.2 & -0.2 & -0.2 & 0.1 & 0.1 & 0.0 \\
\hline 62 & -0.2 & 0.0 & 0.0 & -0.1 & 0.0 & 0.2 & 0.2 & 0.1 \\
\hline 63 & -0.2 & -0.1 & -0.1 & -0.1 & 0.0 & 0.2 & 0.1 & 0.1 \\
\hline 64 & 0.0 & 0.2 & 0.2 & 0.1 & 0.0 & 0.2 & 0.2 & 0.1 \\
\hline 65 & 0.2 & 0.4 & 0.4 & 0.3 & 0.2 & 0.4 & 0.3 & 0.2 \\
\hline 66 & 0.1 & 0.4 & 0.3 & 0.2 & 0.1 & 0.3 & 0.2 & 0.2 \\
\hline 67 & 0.2 & 0.4 & 0.3 & 0.2 & 0.0 & 0.2 & 0.1 & 0.1 \\
\hline
\end{tabular}


At age 62, however, they are eligible for Social Security, and the medical expenses do in fact reduce the amount available for consumption regardless of whether or not they are working. At this point the ACA no longer alters the relative incentives between work and retirement, and the remaining incentives have to do with the income effect of the ACA. These incentives work in the direction of inducing earlier retirement, so the signs of the effects of the ACA tend to change around the time of the Social Security early entitlement age.

Looking at the three income groups in the second through fourth panels, it is evident that the middle income group of the sample with no insurance has the greatest effect of the introduction of the ACA. In the face of high medical expenses, low income workers are more likely to be driven to the minimum consumption standard than are middle income workers, and at that point they become effectively insured. High income workers, on the other hand, are proportionately less affected by medical expenses and hence have a relatively low response to the introduction of the ACA.

Tables 19 and 20 repeat the exercises reported in Tables 17 and 18 except that these tables look at full retirement rather than retirement from full-time work. The effects of the ACA on full retirement seem to follow the same general patterns as for retirement from full-time work, however, so much the same discussion as applied to Tables 17 and 18 also applies to these tables. 
Table 19

Percentage Point Increase in Full Retirement

for Sample with Insurance While Working But No Retiree Coverage

\begin{tabular}{lccccccccc}
\multicolumn{10}{c}{ ACA Introduction Age } \\
Age & 25 & 50 & 55 & 60 & 25 & 50 & 55 & 60 \\
\multicolumn{9}{c}{ All Income Groups } \\
54 & 0.2 & 0.2 & 0.0 & 0.0 & & & & \\
5 & 0.2 & 0.2 & 0.1 & 0.0 & 0.4 & 0.4 & 0.0 & 0.0 \\
5 & 0.2 & 0.4 & 0.4 & 0.1 & 0.0 \\
56 & 0.3 & 0.3 & 0.1 & 0.0 & 0.6 & 0.6 & 0.3 & 0.0 \\
57 & 0.3 & 0.4 & 0.3 & 0.0 & 0.5 & 0.6 & 0.2 & 0.0 \\
58 & 0.2 & 0.3 & 0.3 & 0.0 & 0.2 & 0.3 & 0.2 & 0.0 \\
59 & 0.3 & 0.3 & 0.3 & 0.0 & 0.2 & 0.2 & 0.2 & 0.0 \\
60 & 0.3 & 0.4 & 0.4 & 0.3 & 0.2 & 0.3 & 0.3 & 0.2 \\
61 & 0.4 & 0.5 & 0.5 & 0.5 & 0.2 & 0.3 & 0.4 & 0.4 \\
62 & 0.3 & 0.4 & 0.4 & 0.4 & 0.3 & 0.3 & 0.4 & 0.4 \\
63 & 0.3 & 0.4 & 0.4 & 0.4 & 0.2 & 0.3 & 0.4 & 0.4 \\
64 & 0.2 & 0.3 & 0.3 & 0.3 & 0.3 & 0.4 & 0.5 & 0.5 \\
65 & 0.3 & 0.3 & 0.4 & 0.4 & 0.2 & 0.3 & 0.4 & 0.4 \\
66 & -0.1 & 0.0 & 0.1 & 0.1 & 0.0 & 0.0 & 0.1 & 0.2 \\
67 & -0.1 & 0.0 & 0.1 & 0.1 & -0.1 & -0.1 & 0.0 & 0.1
\end{tabular}

Middle Income Group

High Income Group

$\begin{array}{rrrrrrrrr}54 & 0.2 & 0.2 & 0.0 & 0.0 & 0.1 & 0.1 & 0.0 & 0.0 \\ 55 & 0.2 & 0.2 & 0.0 & 0.0 & 0.1 & 0.1 & 0.1 & 0.0 \\ 56 & 0.2 & 0.2 & 0.1 & 0.0 & 0.2 & 0.2 & 0.2 & 0.0 \\ 57 & 0.2 & 0.2 & 0.2 & 0.0 & 0.2 & 0.2 & 0.2 & 0.0 \\ 58 & 0.2 & 0.2 & 0.2 & 0.0 & 0.2 & 0.3 & 0.3 & 0.0 \\ 59 & 0.3 & 0.3 & 0.4 & 0.0 & 0.4 & 0.4 & 0.4 & 0.0 \\ 60 & 0.5 & 0.5 & 0.6 & 0.5 & 0.3 & 0.4 & 0.4 & 0.4 \\ 61 & 0.5 & 0.5 & 0.5 & 0.5 & 0.3 & 0.4 & 0.4 & 0.4 \\ 62 & 0.5 & 0.5 & 0.5 & 0.5 & 0.3 & 0.3 & 0.4 & 0.4 \\ 63 & 0.5 & 0.5 & 0.5 & 0.5 & 0.2 & 0.3 & 0.3 & 0.3 \\ 64 & 0.3 & 0.3 & 0.3 & 0.3 & 0.1 & 0.2 & 0.2 & 0.2 \\ 65 & 0.4 & 0.4 & 0.5 & 0.5 & 0.2 & 0.3 & 0.3 & 0.3 \\ 66 & -0.1 & 0.0 & 0.1 & 0.1 & -0.1 & 0.0 & 0.1 & 0.1 \\ 67 & -0.1 & -0.1 & 0.0 & 0.0 & -0.1 & 0.0 & 0.1 & 0.1\end{array}$


Table 19 (continued)

Percentage Point Increase in Full Retirement

for Sample with Insurance While Working But No Retiree Coverage

\begin{tabular}{|c|c|c|c|c|c|c|c|c|}
\hline \multirow[b]{2}{*}{ Age } & \multirow[b]{2}{*}{25} & \multicolumn{7}{|c|}{ ACA Introduction Age } \\
\hline & & 50 & 55 & 60 & 25 & 50 & 55 & 60 \\
\hline \multicolumn{5}{|c|}{ Good Health Group } & \multicolumn{4}{|c|}{ Poor Health Group } \\
\hline 54 & 0.2 & 0.2 & 0.0 & 0.0 & 0.3 & 0.3 & 0.0 & 0.0 \\
\hline 55 & 0.1 & 0.1 & 0.0 & 0.0 & 0.3 & 0.3 & 0.2 & 0.0 \\
\hline 56 & 0.2 & 0.2 & 0.1 & 0.0 & 0.4 & 0.5 & 0.4 & 0.0 \\
\hline 57 & 0.3 & 0.3 & 0.2 & 0.0 & 0.3 & 0.4 & 0.3 & 0.0 \\
\hline 58 & 0.2 & 0.2 & 0.2 & 0.0 & 0.3 & 0.4 & 0.4 & 0.0 \\
\hline 59 & 0.3 & 0.3 & 0.2 & 0.0 & 0.3 & 0.4 & 0.4 & 0.0 \\
\hline 60 & 0.4 & 0.5 & 0.4 & 0.4 & 0.2 & 0.3 & 0.4 & 0.3 \\
\hline 61 & 0.4 & 0.5 & 0.5 & 0.4 & 0.1 & 0.2 & 0.3 & 0.4 \\
\hline 62 & 0.3 & 0.4 & 0.4 & 0.3 & 0.4 & 0.4 & 0.5 & 0.6 \\
\hline 63 & 0.4 & 0.5 & 0.5 & 0.5 & 0.2 & 0.3 & 0.4 & 0.5 \\
\hline 64 & 0.3 & 0.3 & 0.3 & 0.3 & 0.2 & 0.3 & 0.3 & 0.4 \\
\hline 65 & 0.3 & 0.3 & 0.4 & 0.4 & 0.3 & 0.3 & 0.4 & 0.4 \\
\hline 66 & 0.0 & 0.0 & 0.1 & 0.1 & 0.0 & 0.0 & 0.1 & 0.1 \\
\hline 67 & -0.1 & 0.0 & 0.1 & 0.1 & -0.1 & 0.0 & 0.1 & 0.1 \\
\hline
\end{tabular}


Table 20

Percentage Point Increase in Full Retirement for Sample with No Insurance Coverage

\begin{tabular}{cccccccccc}
\multicolumn{8}{c}{ ACA Introduction Age } \\
Age & 25 & 50 & 55 & 60 & 25 & 50 & 55 & 60 \\
\multicolumn{7}{c}{ All Income Groups } \\
54 & -0.4 & -0.2 & 0.0 & 0.0 & -0.2 & -0.1 & 0.0 & 0.0 \\
55 & -0.5 & -0.3 & -0.3 & 0.0 & -0.4 & -0.2 & -0.1 & 0.0 \\
56 & -0.4 & -0.3 & -0.2 & 0.0 & -0.3 & -0.1 & -0.1 & 0.0 \\
57 & -0.5 & -0.4 & -0.3 & 0.0 & -0.5 & -0.3 & -0.2 & 0.0 \\
58 & -0.5 & -0.3 & -0.3 & 0.0 & -0.4 & -0.2 & -0.1 & 0.0 \\
59 & -0.7 & -0.5 & -0.4 & 0.0 & -0.7 & -0.4 & -0.4 & 0.0 \\
60 & -0.5 & -0.3 & -0.3 & -0.4 & -0.7 & -0.4 & -0.4 & -0.4 \\
61 & -0.5 & -0.2 & -0.2 & -0.2 & -0.5 & -0.3 & -0.2 & -0.2 \\
62 & -0.5 & -0.3 & -0.3 & -0.4 & -0.7 & -0.5 & -0.5 & -0.5 \\
63 & -0.4 & -0.2 & -0.2 & -0.3 & -0.5 & -0.3 & -0.3 & -0.3 \\
64 & -0.2 & 0.0 & -0.1 & -0.1 & -0.4 & -0.2 & -0.2 & -0.2 \\
65 & 0.4 & 0.6 & 0.6 & 0.5 & 0.4 & 0.6 & 0.6 & 0.5 \\
66 & 0.2 & 0.4 & 0.4 & 0.3 & 0.2 & 0.4 & 0.4 & 0.3 \\
67 & 0.1 & 0.3 & 0.3 & 0.2 & 0.1 & 0.3 & 0.2 & 0.2
\end{tabular}

Middle Income Group

High Income Group

$\begin{array}{rrrrrrrrr}54 & -0.9 & -0.9 & 0.0 & 0.0 & -0.3 & -0.2 & 0.0 & 0.0 \\ 55 & -1.1 & -1.0 & -0.8 & 0.0 & -0.3 & -0.1 & -0.2 & 0.0 \\ 56 & -0.8 & -0.7 & -0.6 & 0.0 & -0.2 & -0.1 & -0.1 & 0.0 \\ 57 & -0.9 & -0.8 & -0.7 & 0.0 & -0.4 & -0.2 & -0.3 & 0.0 \\ 58 & -0.8 & -0.7 & -0.6 & 0.0 & -0.4 & -0.2 & -0.3 & 0.0 \\ 59 & -1.2 & -1.1 & -1.1 & 0.0 & -0.3 & -0.1 & -0.2 & 0.0 \\ 60 & -0.5 & -0.4 & -0.4 & -0.6 & -0.1 & 0.0 & 0.0 & -0.2 \\ 61 & -0.4 & -0.2 & -0.2 & -0.3 & -0.2 & -0.1 & -0.1 & -0.2 \\ 62 & -0.5 & -0.4 & -0.4 & -0.5 & -0.2 & 0.0 & -0.1 & -0.1 \\ 63 & -0.3 & -0.1 & -0.1 & -0.2 & -0.3 & -0.2 & -0.2 & -0.3 \\ 64 & 0.0 & 0.2 & 0.1 & 0.0 & 0.0 & 0.1 & 0.1 & 0.0 \\ 65 & 0.4 & 0.5 & 0.5 & 0.4 & 0.5 & 0.6 & 0.6 & 0.5 \\ 66 & 0.3 & 0.5 & 0.5 & 0.3 & 0.1 & 0.3 & 0.2 & 0.2 \\ 67 & 0.2 & 0.4 & 0.4 & 0.2 & 0.1 & 0.3 & 0.2 & 0.2\end{array}$


Table 20 (continued)

Percentage Point Increase in Full Retirement for Sample with No Insurance Coverage

\begin{tabular}{|c|c|c|c|c|c|c|c|c|}
\hline \multirow[b]{2}{*}{ Age } & \multicolumn{8}{|c|}{ ACA Introduction Age } \\
\hline & 25 & 50 & 55 & 60 & 25 & 50 & 55 & 60 \\
\hline \multicolumn{5}{|c|}{ Good Health Group } & \multicolumn{4}{|c|}{ Poor Health Group } \\
\hline 54 & -0.4 & -0.3 & 0.0 & 0.0 & -0.6 & -0.4 & 0.0 & 0.0 \\
\hline 55 & -0.5 & -0.3 & -0.2 & 0.0 & -0.5 & -0.2 & -0.2 & 0.0 \\
\hline 56 & -0.3 & -0.2 & -0.2 & 0.0 & -0.5 & -0.3 & -0.2 & 0.0 \\
\hline 57 & -0.6 & -0.4 & -0.4 & 0.0 & -0.5 & -0.3 & -0.3 & 0.0 \\
\hline 58 & -0.5 & -0.4 & -0.3 & 0.0 & -0.5 & -0.3 & -0.2 & 0.0 \\
\hline 59 & -0.7 & -0.6 & -0.5 & 0.0 & -0.5 & -0.3 & -0.3 & 0.0 \\
\hline 60 & -0.6 & -0.4 & -0.4 & -0.5 & -0.4 & -0.2 & -0.2 & -0.3 \\
\hline 61 & -0.5 & -0.4 & -0.3 & -0.3 & -0.3 & -0.1 & -0.1 & -0.1 \\
\hline 62 & -0.6 & -0.5 & -0.5 & -0.5 & -0.3 & 0.0 & -0.1 & -0.2 \\
\hline 63 & -0.5 & -0.4 & -0.4 & -0.4 & -0.1 & 0.1 & 0.1 & 0.0 \\
\hline 64 & -0.2 & -0.1 & -0.1 & -0.1 & -0.1 & 0.2 & 0.1 & 0.1 \\
\hline 65 & 0.5 & 0.7 & 0.7 & 0.6 & 0.3 & 0.6 & 0.5 & 0.5 \\
\hline 66 & 0.1 & 0.3 & 0.3 & 0.2 & 0.1 & 0.3 & 0.3 & 0.2 \\
\hline 67 & 0.1 & 0.3 & 0.3 & 0.2 & 0.1 & 0.3 & 0.3 & 0.2 \\
\hline
\end{tabular}




\section{Conclusions}

Simulations based on a previously estimated structural model of retirement and saving suggest that the group subject to the largest marginal effect on their retirement incentives from Affordable Care Act - those who initially had health insurance at work but not in retirement -will increase their retirement as a result of passage of ACA. But the reduction in work effort is quite modest, amounting to an increase of half a percentage point per year in the percent retired. These simulations also suggest that the period of adjustment to a change in the law will be relatively short. In contrast, they suggest that ACA will reduce the probability of retirement at earlier ages by those who had no health insurance coverage either at work or in retirement prior to ACA.

Empirical data indicating the actual changes in retirement and retirement intentions observed to date are consistent with the simulations based on the structural model estimated with pre-ACA data. There is no statistically significant evidence in HRS panel data that respondents who initially had health insurance at work, but not in retirement, have begun to retire early as a result of ACA. Nor is there evidence of changes in expected retirement dates and dates of claiming Social Security as a result of adoption of ACA.

The simulations based on the structural model lead us to expect only small changes in retirement as a result of ACA, even in the long term. It is, however, possible that once ACA has been in place for a while, changes might be found in actual and expected retirements. The current strong penalties for not conforming to ACA have only just come on line. Thus at the time of the HRS survey of Mid Boomers in 2014, people may not yet have focused on the implications of the law for their looming retirement, and therefore may not have changed either their retirement behavior or their retirement intensions in response. Moreover, looking forward to the 2016 HRS 
survey results, there are a couple of other reasons why one might expect to eventually find some effects of ACA on retirement. First, despite a temporary program to subsidize employer provided health insurance for early retirees (WHITEHOUSE.GOV/HEALTH REFORM), employer offerings of early retiree coverage will probably decline further (Kaiser Family Foundation, 2016). As a result, the group most affected by the change in incentives (the "current employer coverage/early retiree coverage NOT available") will grow. That would yield larger effects in the medium/long run. Second, should more states expand Medicaid over time, that would also mean a larger effect.

Nevertheless, we did not uncover any evidence to suggest that ACA will have large effects on retirement. Thus the effects of ACA on retirement would, at most, have only a minor influence on any evaluations of ACA. Both supporters and critics will have to look elsewhere when drawing conclusions about the welfare effects of ACA. 


\section{References:}

Clark, Robert L. 2015. “Retiree Health Insurance and the Retirement Plans of College and University Faculty”. Journal of Retirement. Winter: 55-66.

Coile, Courtney, Peter Diamond, Jonathan Gruber and Alain Jousten. 2002. "Delays in claiming Social Security benefits”. Journal of Public Economics 84: 357-385.

Currie, Janet and Brigitte C. Madrian. 1999. "Health, Health Insurance and the Labor Market”. In Orley Ashenfelter and David Card, Editors. Handbook of Labor Economics 3 (Part C): 3309 to 3416. Elsevier.

French, Eric and John Bailey Jones. 2011. "The Effects of Health Insurance and Self-Insurance on Retirement Behavior." Econometrica 79(3): 693-732.

Gilleskie, Donna B. and David M. Blau, 2006. "Health Insurance and Retirement of Married Couples."Journal of Applied Econometrics 21(7): 935-953.

Glickman, Mark M. and Sharon Hermes. 2015. "Why Retirees Claim Social Security at 62 and How It Affects Their Retirement Income: Evidence from the Health and Retirement Study”. The Journal of Retirement (Winter): 25-39.

Gustman, Alan L. and Thomas L. Steinmeier. 1994. "Employer Provided Health Insurance and Retirement Behavior". Industrial and Labor Relations Review 48(1): 124-140. . 2000. "Pensions and Retiree Health Benefits In Household Wealth:

Changes From 1969 to 1992". Journal of Human Resources 35(1): 30-50. . 2005. "The Social Security Early Retirement Age In A Structural Model of Retirement and Wealth.” Journal of Public Economics 89(2-3): 441-463. . 2014. “Integrating Retirement Models”. Research in Labor Economics 80, 2014: 81-114. 
2015. "Effects of Social Security Policies on Benefit Claiming, Retirement and Saving. Journal of Public Economics. September 2015, 129: 51-62. . Forthcoming. "The Role of Health in Retirement”. Research in Labor Economics 80, 2014: . An earlier version appeared in NBER Working Paper 19902, February, 2014.

Hubbard, R. Glenn, Jonathan Skinner and Stephen P. Zeldes. 1995. "Precautionary Saving and Social Insurance”. Journal of Political Economy 103(2): 360-399.

Henriques, Alice M. 2012. “How Does Social Security Claiming Respond to Incentives? Considering Husbands’ and Wives’ Benefits Separately”. Washington, D.C. Federal Reserve Board.

Kaiser Family Foundation. 2016. "Retiree Health Benefits at the Crossroads”. Report, April. Karoly, Lynn A. and Jeanette Rogowski. 1994. Industrial and Labor Relations Review 48(1): 103-123.

Levy, Helen, Thomas Buchmueller and Sayeh Nikpay. 2015. “The Effect of Health Reform on Retirement”. Michigan Retirement Research Center, Working Paper 2015-329. September.

Madrian, Brigitte C. 1994. “The Effect of Health Insurance on Retirement”. Brookings Papers on Economic Activity 25 (1): 181-252.

Marton, James and Stephen A. Woodbury. 2006. "Retiree Health Benefits and Retirement". W.E. Upjohn Institute staff working paper no. 06-128.

Nyce, Steven, Sylvester Schieber, John B. Shoven, Sita Slavov and David A. Wise. 2011. "Does Retiree Health Insurance Encourage Early Retirement?” NBER Working Paper No. 17703. December. 
Rust, John and Christoper Phelan. 1997. "How Social Security and Medicare Affect Retirement”. Econometrica 65(4):781-831.

Shoven, John B and Sita Nataraj Slavov. 2012."The Decision to Delay Social Security Benefits: Theory and Evidence". NBER Working Paper No. 17866. . 2014. "The role of retiree health insurance in the early retirement of public sector employees," Journal of Health Economics 38(C): 99-108.

Song, Jae and Joyce Manchester. 2007. "Have People Delayed Claiming Retirement Benefits?" Social Security Bulletin 67(2): 1-23.

WHITEHOUSE.GOV/HEALTH REFORM. "Health Reform for Early Retirees: The Affordable Care Act Gives Early Retirees Greater Control Over Their Own Health Care”. (Https://www.whitehouse.gov/sites/default/files/rss_viewer/health_reform_for_early_reti rees.pdf) 
Appendix Table 1: Number of Respondents by the Source of Insurance for Early Boomers in 2004 and 2008- Same Sample

\begin{tabular}{|c|c|c|c|c|c|c|c|c|c|c|}
\hline & \multicolumn{10}{|c|}{2008} \\
\hline 2004 & $\begin{array}{c}\text { Current } \\
\text { Employer } \\
\\
1\end{array}$ & $\begin{array}{l}\text { Previous } \\
\text { Employer } \\
\\
2\end{array}$ & $\begin{array}{l}\text { Self } \\
\text { Emp- } \\
\text { loyed } \\
\text { Bus- } \\
\text { iness } \\
3\end{array}$ & $\begin{array}{c}\text { Spouse } \\
\text { Employer } \\
\text { - current } \\
\text { or former } \\
4\end{array}$ & $\begin{array}{c}\text { Private } \\
\text { Insurance } \\
\text { Purchase } \\
\\
5\end{array}$ & $\begin{array}{l}\text { Medicare } \\
\text { (disabil- } \\
\text { ity?) }\end{array}$ & $\begin{array}{c}\text { Medi- } \\
\text { caid } \\
\\
7\end{array}$ & Military & $\begin{array}{c}\text { No } \\
\text { insur- } \\
\text { ance } \\
\\
11\end{array}$ & $\begin{array}{c}\text { Row } \\
\text { Total } \\
\\
12\end{array}$ \\
\hline 1-Current Employer & 648 & 28 & 7 & 26 & 9 & 0 & 0 & 5 & 43 & $\begin{array}{l}766 \\
59 \%\end{array}$ \\
\hline 2-Previous Employer & 6 & 22 & 0 & 1 & 1 & 0 & 0 & 2 & 4 & $\begin{array}{c}36 \\
3 \%\end{array}$ \\
\hline $\begin{array}{l}\text { 3-Self Employed } \\
\text { Business }\end{array}$ & 4 & 1 & 25 & 5 & 6 & 0 & 0 & 0 & 2 & $\begin{array}{l}43 \\
3 \%\end{array}$ \\
\hline $\begin{array}{l}\text { 4-Spouse Employer - } \\
\text { current or former }\end{array}$ & 36 & 3 & 2 & 137 & 2 & 0 & 0 & 1 & 11 & $\begin{array}{l}192 \\
15 \%\end{array}$ \\
\hline $\begin{array}{l}\text { 5-Private Insurance } \\
\text { Purchase (includes } \\
\text { AARP and others) }\end{array}$ & 13 & 1 & 10 & 3 & 16 & 0 & 0 & 0 & 11 & $\begin{array}{l}54 \\
4 \%\end{array}$ \\
\hline 6-Medicare (disability?) & 0 & 0 & 0 & 1 & 0 & 2 & 0 & 0 & 0 & $\begin{array}{c}3 \\
0 \%\end{array}$ \\
\hline 7-Medicaid & 3 & 0 & 0 & 0 & 2 & 2 & 0 & 0 & 6 & $\begin{array}{c}13 \\
1 \%\end{array}$ \\
\hline 8- Military & 3 & 0 & 0 & 0 & 0 & 0 & 0 & 10 & 2 & $\begin{array}{l}15 \\
1 \%\end{array}$ \\
\hline 9-No insurance & 46 & 2 & 1 & 22 & 11 & 0 & 4 & 4 & 96 & $\begin{array}{l}186 \\
14 \%\end{array}$ \\
\hline 10-Column Total & $\begin{array}{l}759 \\
58 \%\end{array}$ & $\begin{array}{l}57 \\
4 \%\end{array}$ & $\begin{array}{l}46 \\
4 \%\end{array}$ & $\begin{array}{l}195 \\
15 \%\end{array}$ & $\begin{array}{l}47 \\
4 \%\end{array}$ & $\begin{array}{c}4 \\
0 \%\end{array}$ & $\begin{array}{c}4 \\
0 \%\end{array}$ & $\begin{array}{l}22 \\
2 \%\end{array}$ & $\begin{array}{c}174 \\
13 \%\end{array}$ & $\begin{array}{c}1309 \\
100 \%\end{array}$ \\
\hline
\end{tabular}

* This sample is constrained to include those who were currently employed in 2004 and in 2008. 
Appendix Table 2: Expected Ages of Social Security Benefit Claiming and Retirement, weighted*

\begin{tabular}{|l|c|c|c|}
\hline & 2010 & 2012 & 2014 \\
\hline \multicolumn{2}{|c|}{ Expected Age of Benefit Claiming } \\
\hline $\begin{array}{l}\text { HI on Job; No HI in Retirement in } \\
2010\end{array}$ & 65.4 & 65.4 & 65.3 \\
\hline $\begin{array}{l}\text { No HI on Job; No HI in Retirement in } \\
2010\end{array}$ & 65.0 & 65.2 & 64.7 \\
\hline HI on Job; HI in Retirement in 2010 & 64.9 & 65.3 & 64.8 \\
\hline \multicolumn{2}{|c|}{ Expected Age of Retirement } \\
\hline $\begin{array}{l}\text { HI on Job; No HI in Retirement in } \\
2010\end{array}$ & 64.3 & 65.0 & 65.1 \\
\hline $\begin{array}{l}\text { No HI on Job; No HI in Retirement in } \\
\text { 2010 }\end{array}$ & 64.7 & 64.8 & 65.0 \\
\hline HI on Job; HI in Retirement in 2010 & 64.3 & 64.9 & 64.6 \\
\hline
\end{tabular}

Similar to Table 12 but with respondents with missing claim age or retirement age excluded.

Number of observations in the sample is 962. 